
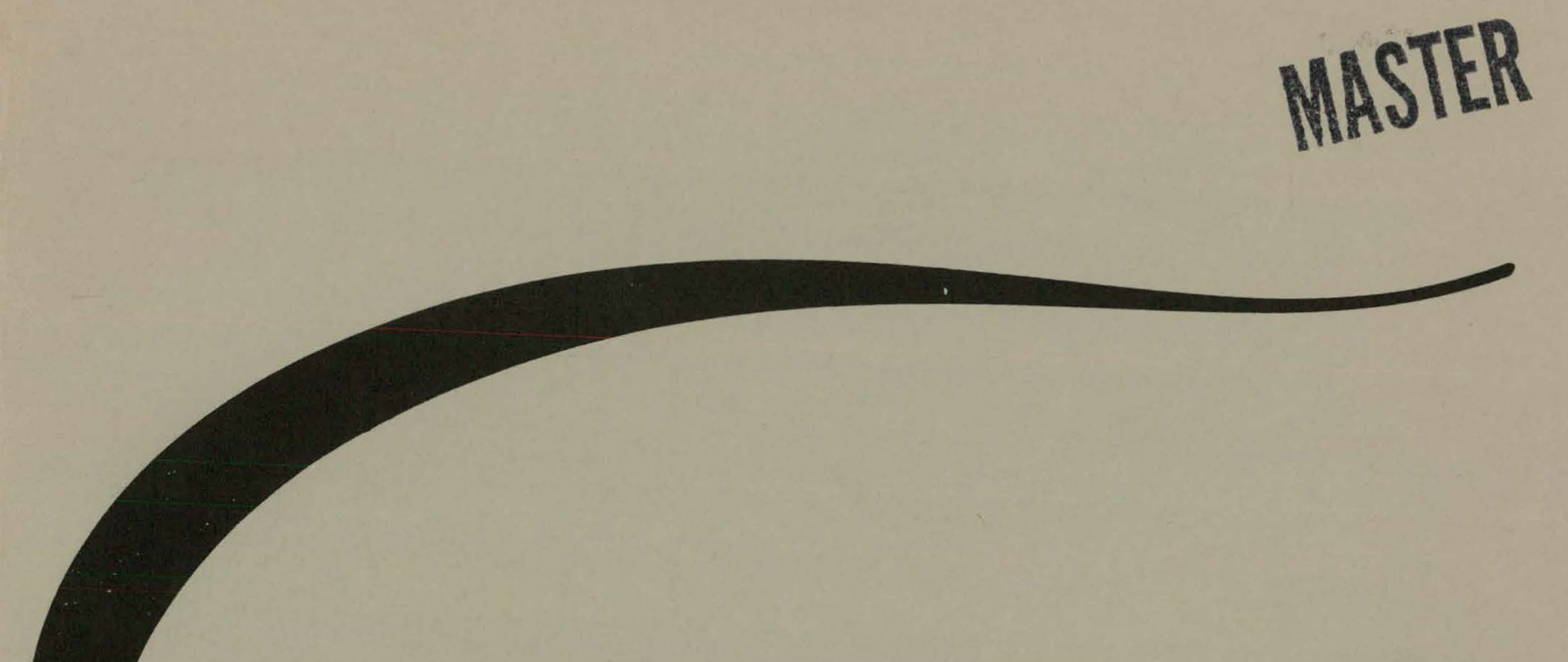

A COMPUTER PROGRAM FOR DETERMINING

THE GROWTH OF NUCLIDES FROM RADIOACTIVE DECAY

Charles R. Forrey, Jr.

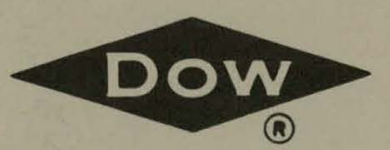

THE DOW CHEMICAL COMPANY ROCKY FLATS DIVISION

P. O. BOX 888

GOLDEN, COLORADO 80401

U.S. ATOMIC ENERGY COMMISSION CONTRACT AT(29-1)-1106 


\section{DISCLAIMER}

This report was prepared as an account of work sponsored by an agency of the United States Government. Neither the United States Government nor any agency Thereof, nor any of their employees, makes any warranty, express or implied, or assumes any legal liability or responsibility for the accuracy, completeness, or usefulness of any information, apparatus, product, or process disclosed, or represents that its use would not infringe privately owned rights. Reference herein to any specific commercial product, process, or service by trade name, trademark, manufacturer, or otherwise does not necessarily constitute or imply its endorsement, recommendation, or favoring by the United States Government or any agency thereof. The views and opinions of authors expressed herein do not necessarily state or reflect those of the United States Government or any agency thereof. 


\section{DISCLAIMER}

Portions of this document may be illegible in electronic image products. Images are produced from the best available original document. 
This report was prepared as an account of Government sponsored work. Neither the United States, nor the Commission, nor any person acting on behalf of the Commission:

A. Makes any warranty or representation, expressed or implied, with respect to the accuracy, completeness, or usefulness of the information contained in this report, or that the use of any information, apparatus, method, or process disclosed in this report may not infringe privately owned rights; or

B. Assumes any liabilities with respect to the use of, or for damages resulting from the use of any information, apparatus, method, or process disclosed in this report.

As used in the above, "person acting on behalf of the Commission" includes any employee or contractor of the Commission, or employee of such contractor, to the extent that such employee or contractor of the Commission, or employee of such contractor prepares, disseminates, or provides access to, any information pursuant to his employment or contract with the Commission, or his employment with such contractor.

Printed in the United States of America

Available from

Clearinghouse for Federal Scientific and Technical Information

National Bureau of Standards, U. S. Department of Commerce

Springfield, Virginia 22151

Price: Printed Copy $\$ 3.00 ;$ Microfiche $\$ 0.65$ 


\title{
A COMPUTER PROGRAM FOR DETERMINING THE GROWTH OF NUCLIDES FROM RADIOACTIVE DECAY
}

\author{
Charles R. Forrey, Jr.
}

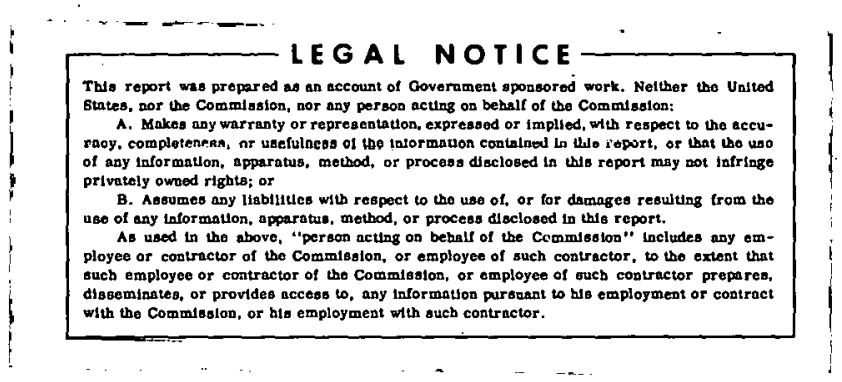
THE DOW CHEMICAL COMPANY ROCKY FLATS DIVISION
P. O. BOX 888 GOLDEN, COLORADO 80401
U. 5. ATOMIC ENERGY COMMISSION CONTRACT AT(29-1)-1106




\section{THIS PAGE}

\section{WAS INTENTIONALLY \\ LEFT BLANK}




\section{CONTENTS}




ACKNOWLEDGMENTS

I want to express my appreciation to George Van Trump of the Computer Development Group for modifying an existing computer program to accept this problem, and to Harvey Hascall for subsequently rewriting and streamlining the program and originating the flow chart. 


\title{
A COMPUTER PROGRAM FOR DETERMINING THE GRONTH OF NUCLIDES FROM RADIOACTIVE DECAY
}

\author{
Charles R. Forrey, Jr.
}

\begin{abstract}
A computer program was written for extrapolating the quantities of nuclides that are or will be present in radioactive material previously analyzed for isotopic content by radiochemical methods.
\end{abstract}

\section{SUMMARY}

A modified Isogen (Iso tope Generation) computer program was devised that can be used:

1. To determine the change in isotopic concentration of an element; hence, to determine the specific activity over extended periods of time.

2. To determine procedures necessary to analyze for any particular element.

3. To determine if nuclides or elements are present in detectable quantities.

4. To predict the isotopic concentration and impurity content of the final product at any given time in the future.

\section{INTRODUCTION}

The isotopic content of any radioactive material is constantly changing because of natural radioactive decay. The concentration of isotopes (some of which are regarded as impurities in certain applications) is of interest to those who use radiochemical methods of analysis and to those who must maintain or know the purity of the final product.

The isotopic content of a given piece of radioactive material is normally determined by radiochemical analysis at some point during processing. However, after the material passes a certain stage of processing, it usually is no longer possible or practicable to re-analyze it. Since radioactive materials decay at known rates and in known cycles, it seemed possible to use a computer to extrapolate information about isutupic content, presuming the content was previously determined by analysis. Described in this report is the modified Isogen computer program that was devised. The program makes it possible to compute the concentration of all nuclides in previously analyzed radioactive material without reanalyzing the material.

\section{DISCUSSION}

- A literature search of computer programs revealed a program similar to the one desired. " The program was modified to remove procedures about reactor operations leaving procedures for calculating the concentrations of radioactive decay products. The list of nuclides was expanded to more than 300 , ranging from atomic numbers 81 through 102 . A time sequence element was added, making it possible to compute decay producls for any selected time increment. Also, to aid laboratories performing radiochemical analyses, an additional step was included to permit computing the alpha and beta disintegrations for each nuclide present. The latter information is especially helpful for determining how to analyze for any particular nuclide and for determining whether sufficient nuclides are present to be detectable by radiochemical methods.

The accuracy of the program depends on how accurately the decay modes and half-lives of the nuclides are known. The half-lives of many nuclides have been determined by a number of people using a variety of methods. ${ }^{2}$ The results they have obtained vary to some extent, which introduces an uncertainty into the computations. In most cases, however, this variation causes only insignificant errors. The computer program was written so it could be changed easily as new information about decay modes and half-lives becomes available.

Because of the size and complexity of the modified Isogen program, it was originally written for the Control Data Corporation Model 3600 computer at the National Bureau of Standards in Boulder, Colorado. After installation of a large memory computer, the program was adapted to the International Businees Machines 360 Model 40 computer at the Rocky Flats Division of The Dow Chemical Company. A problem of average complexity, such as the one 
described below, can be run on the Rocky Flats computer in approximately $1 \frac{1}{2}$ minutes including printout time. At the current rate of $\$ 385$ per hour for computer time, it costs $\$ 9.63$ to complete such a problem. Since the nuclide library information is stored on discs in the computer, thus providing direct access, no loading time is required. (NonRocky Flats users would be charged approximately $\$ 15$ per month to have comparable programs filed and stored at Rocky Flats.)

To illustrate how the program performs the desired operation, assume that at some specific time an ingot of plutonium was analyzed and found to conLain the fulluwing isotopes:

$$
\begin{aligned}
& { }^{238} \mathrm{Pu}-0.0030 \% \\
& { }^{2.39} \mathrm{Pu}-97.00 \% \\
& { }^{240} \mathrm{Pu}-2.62 \% \\
& { }^{241} \mathrm{Pu}-0.38 \% \\
& { }^{242} \mathrm{Pu}-0.0029 \% \\
& { }^{241} \mathrm{Am}-0.0426 \%
\end{aligned}
$$

Twenty-seven months later, this ingot is to be used and its isotopic concentration and impurity level need to be determined. The problem is run through the computer, resulting in the printout included as Appen$\operatorname{dix} \mathrm{A}$. The printout shows the current isotopic content to be:

$$
\begin{aligned}
& { }^{238} \mathrm{Pu}-0.0029459 \% \\
& { }^{239} \mathrm{Pu}-96.994 \% \\
& { }^{240} \mathrm{Pu}-2.6194 \% \\
& { }^{241} \mathrm{Pu}-0.34002 \% \\
& { }^{242} \mathrm{Pu}-0.00290 \% \\
& { }^{241} \mathrm{Am}-0.08235 \%
\end{aligned}
$$

The printout also shows the quantities present of 57 other nuclides.

From the sample printout, it $\mathrm{c}$ an be determined that the only significant change in isotopic content was in ${ }^{24} \mathrm{Pu}$, which decreased 10.5 percent. The printout also reveals that the impurity concentration of ${ }^{241} \mathrm{Am}$ doubled, and that ${ }^{237} \mathrm{~Np},{ }^{234} \mathrm{U},{ }^{235} \mathrm{U},{ }^{236} \mathrm{U},{ }^{237} \mathrm{U}$, and ${ }^{233} \mathrm{~Pa}$ are present in sufficient quantities to be of interest to those interested in radiometric counting procedures or in the production of ultrapure plutonium. The remainder of the nuclides listed are present in quantities sufficiently small to be of interest only to confirm the ir insignificance. However, in laboratories and production facilities both, confirming the absence of an element is often as

\begin{tabular}{|c|c|c|}
\hline Cards 1 through $\mathrm{N}$ & & Nuclide Library \\
\hline Card $N$ plus 1 & & Number of Time Steps \\
\hline Card $\mathrm{N}$ plus 2 & & $\begin{array}{l}\text { Time Steps, Time, and } \\
\text { Time Code }\end{array}$ \\
\hline Card N plus 3 & - & $\begin{array}{l}\text { Number of Beginning } \\
\text { Nuclides (Parents) }\end{array}$ \\
\hline Card N p & & $\begin{array}{l}\text { Parents' Identity and } \\
\text { Starting Quantities }\end{array}$ \\
\hline
\end{tabular}
important as determining its presence.

\section{PROGRAM DESCRIPTION}

Described in this section is the modified Isogen radioactive decay computer program. Included is information about (1) the makeup of the input data deck, (2) the computer operational sequence, and (3) a flow chart of the computer program.

\section{Input Data Deck:}

The input deck is composed of the following five kinds of cards. which are listed in the order in which they are arranged.

Cards 1 through $\mathbf{N}$ - Nuclide Library:

The nuclide library cards describe the decay properties of the elements. One card is made for each element included in the program. Given in the upper portion of Table! is the information punched into the nurlide library cards:

The isotopic identification appearing in column 9 of the nuclide library cards is always either an " $\mathrm{M}$ " or a blank. The time code in column 16 is 1 through 5 , where in 1 represents seconds, 2 represents minutes, 3 represents hours, 4 represents days, and 5 represents years. In column 26 , the decay code is 1 through 5, wherein 1 designates alpha decay, 2 designates beta emission, 3 designates electron capture, 4 designates isomeric transition, and 5 designates spontaneous fission. The information included on the nuclide library cards should rarely change.

\section{Card $\mathbf{N}$ plus 1 - Number of Time Steps:}

Card $\mathrm{N}$ plus $\mathrm{l}$ contains the number of time steps, of which there can be no more than 30 . That is, the card is punched with a number from 001 to 030 in columns 1 through 3 , as shown in Table I. 
Table I. Information punched into data deck.

\begin{tabular}{|c|c|c|c|c|}
\hline Card & Columns & Format & Identification & Example \\
\hline \multirow[t]{11}{*}{1 through $\mathrm{N}$} & $1-3$ & 13 & Element identification number & 111 \\
\hline & 4-5 & A2 & Atomic symbol & NP \\
\hline & $6-8$ & F 3.0 & Atomic weight & 236 \\
\hline & 9 & Al & Isotopic identification & $\mathrm{M}$ \\
\hline & $10-15$ & E6.3 & Half-life number & $2200+1$ \\
\hline & 16 & 11 & Time code & 3 \\
\hline & $17-22$ & E6.3 & Minor branch & $5000-1$ \\
\hline & $23-25$ & I3 & Major daughter & 101 \\
\hline & 26 & Il & Decay code & 2 \\
\hline & $27-29$ & I3 & Minor daughter & 116 \\
\hline & 30 & Il & Decay code & 3 \\
\hline N plus 1 & $.1-3$ & I3 & Number of time stens & 003 \\
\hline \multirow[t]{2}{*}{$\mathrm{N}$ plus 2} & $1-6$ & E6.3 & Time & $7263+3$ \\
\hline & 7 & Il & Time code & 4 \\
\hline N plus 3 & $1-3$ & I3 & Number of Parents & 003 \\
\hline \multirow{3}{*}{$\mathrm{N}$ plus 4} & $1-3$ & I3 & Element identification number & 077 \\
\hline & $4-9$ & E6.3 & Amount & $2000-3$ \\
\hline & 10 & Il & Amount code & 3 \\
\hline
\end{tabular}

Card $\mathbf{N}$ plus 2 - Time Steps, Time, and T'ime Code:

The information punched on Card $\mathrm{N}$ plus 2 defines the time steps (time increments - i.e., every month, every two years, etc.), the time (how many seconds, minutes, etc.), and the time code (seconds, minutes, hours, days, years). The information is punched into columns 1 through 7 (see Table I); it is repeated in columns 8 through 14,15 through 21 , etc., as necessary to define the required number of time steps (up to a maximum of 10 steps per card). For example, the term $7263+34$ punched in columns 1 through 7 means $7.263+10^{3}$ days or 7263 days. The first four digits represent the number of time units; the plus sign and the following digit 3 indicate the power of 10 ; and the final digit 4 is the symbol representing days, as previously defined in column 16 of the nuclide library cards.

\section{Card $N$ plus 3 - Number of Parents:}

The number of starting elements (parents) for each particular problem is indicated in columns 1 through 3 of this card. The information must be "right adjusted" when it is punched onto the card. That is, if there are only six parents, the digit 6 is punched in column 3 . Columns 1 and 2 remain blank.

At the end of each data set, the computer attempts to read a now number of parents. If the value is 0 , the computer returns to read a new number of time steps (Card N plus 1) and begins processing a new data set from that point. If the value is a positive number, a new set of parents is identified (from Card N plus 4). and the information is processed through the designated time steps.

\section{Card N plus 4 - Parents' Identity and Starting Quantities:}

This card identifies the parents (the starting material of each problem), the starting weight of each parent, and the weight unit used. Columns 1 through 3 show the element identification number, from the nuclide library. Columns 4 through 10 show the weight and weight unit, in a manner comparable to the example given for Card $\mathrm{N}$ plus 2. The final digit, however, is symbolized in the following way:

\section{1 represents atoms \\ 2 represents grams \\ 3 represents pounds \\ 4 represents tons \\ 5 represents curies}

The above information is repeated in columns 11 through 20,21 through 30 , and so forth as necessary to identify the designated number of parents. There can be a maximum of seven parents per card, with a lotal maximum of ten.

\section{Computer Operational Sequence:}

The complete computer operational sequence for the modified Isogen program is included as Appendix B. 
Modified Isogen Program Flow Chart:

The operational steps required to execute the modified lsogen computer program are depicted in the flow chart included as Appendix C.

\section{REFERENCES}

1. H. H. Van Tuyl, "Isogen - A Computer Code for Radioisotope Generation Calculations," HW-83785,
September, 1964, General Electric Company, Hanford Atomic Products Operation, Richland, Washington.

2. C. R. Forrey, Jr., "Radiation Half-Lives and Decay Modes for Elements 77 to 102," Internal Report CRDL 940566-5, February 7, 1966, Rocky Flats Division, The Dow Chemical Company. 
APPENDIX A. PRINTOUT OF TYPICAL PROBLEM 
ISOGEN

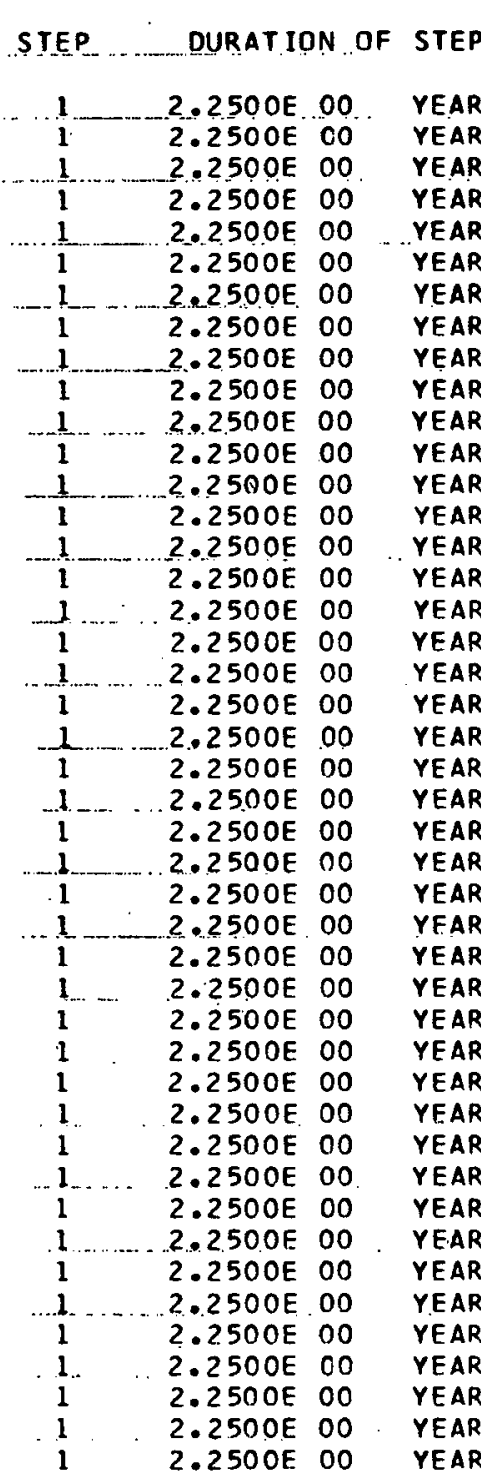

*** RESULTS ***

SYMBOL ATOMS

PU240

U 236

TH23?

TH228

AC228

RA228

RA224

RN220

PO216

$P 0212$
$B 1212$

PB212

TL208

PB208

AM241

PU241

NP 237

U 237

U 233

PA233

TH229

AC225

RA225

FR221

FR221

AT217

P0213

81213

PB209

TL209

BI 209

PU242

PU242

U 238

$\begin{array}{lll}U & 238 \\ U & 234\end{array}$

$\begin{array}{ll}U & 234 \\ \text { PA234.M } & \text { TH }\end{array}$

TH234

TH230

RA226

RN222

AT218

P0218

P0214

BI 214

PB214
6.5735506019

1.5535197016

5.0689172008

9.00085660-04

1.86622560-06

$1.7904363 \mathrm{D}-02$

4.5830941D-06

$8.05873140-10$

2. 30249450-12

2.92768350-18

$5.2728282 \mathrm{D}-08$

5.54456460-07

$9.10485740-10$

$1.46625460-04$

2.0580611018

8.4977265018

5.7015481015

4.4831726011

1.6726955009

1.8756769008

4.84184950 03

$1.56385570-02$

$2.45543850-02$

$5.2127002 D-06$

$3.25800770-10$

$7.09387850-14$

$5.10450260-05$

2.09636330-04

4.77778330-08

$1.97085980-01$

7.2176032016 7.4577390016

3.0924429011

1.3427054015

$1.47324300-04$

4.3328427000

4.2344690009

2. 9309623004

$1.85356540-01$

$1.68347310-10$

$1.02691860-04$

8.8629283D-1

$6.6317618 \mathrm{D}-04$

$9.02072470-04$
GRAMS

$2.61937950-02$ $6.08717700-06$ $1.95249690-13$ $3.40726460-25$ $7.06457680-28$ $6.77767740-24$ 1.70448810-27 $2.94358470-31$ $8.25732780-34$ $1.03049800-39$ $1.85595160-29$ $1.95159850-28$ 3.14429760-31 $5.06360580-26$ $8.23497840-04$ $3.40021960-03$ 2.24351150-06 1.76409090-10 $6.47082970-13$ $7.25606430-14$ $1.84091580-18$ $5.84206460-24$ $9.17273270-24$ $1.9126794 \mathrm{D}-27$ $1.17381320-31$ 2.50871030-35 $1.80517870-26$ $7.27444710-26$ $1.65790600-29$ $2.89998350-05$ $2.94694010-05$ $1.2219848 \mathrm{D}-10$ $5.21655460-07$ $5.72370700-26$ $1.6833559 \mathrm{D}-21$ $1.61701470-12$ $1.09978000-17$ $6.83200300-23$ $6.09326190-32$ $3.71688970-26$ 3.14904000-32 $2.35629610-25$

3.20510580-25
CURIES

$5.91246020-03$ $3.8586114 D-10$ 2.16477390-20 $2.79745200-22$ 1. $58424630-21$ $1.5863393 \mathrm{D}-21$ $2.73001630-22$ 2.73000360-22 $2.73000300-22$ 1.80414 $2.72118750-22$ $2.72195290-22$ $9.17026270-23$ 0.0

2.82347270-03 3.5954829D-01 $1.58157990-09$ 1.44008930-05 $6.12934340-15$ $1.48427920-09$ $3.91586190-19$ $3.39081730-19$ $3.59728950-19$ 3.39072140-19 3.39079220-19 $3.32234940-19$ $3.39098430-19$ $3.3878948 \mathrm{D}-19$ $6.7806927 D-21$ 0.0

$1.17707360-07$ $5.06533050-04$ $4.07040400-17$ $3.21396480-09$ 3.89818930-17 3.89819740-17 $3.34266740-14$ $1.0726830 \mathrm{D}-17$ $1.05126300-17$ $2.10250210-21$ $1.05125130-17$ $1.0508522 \mathrm{D}-17$ $1.05107340-17$ $1.05093790-17$

\section{ALPHA DECAY DISIMIN}

1.3129718010

8.56876860 .02 4. $80728470-08$ $6.21226610-10$ 0.0

0.0

$6.06253930-10$ $6.06251090-10$ $6.06251020-10$ 4.00646600-10 $2.0364684 \mathrm{D}-10$ 0.0 0.0 6.2700459009 $3.19377560 \quad 07$ $3.51219420 \quad 03$ 0.0 $1.36113490-02$ 0.0 8.69589990-07 $7.52997910-07$ 0.0

$7.52976080-07$ $7.52992280-07$ $7.37793340-07$ $1.50607000-08$ 0.0

0.0

$2.61391180 \quad 05$ $1.12485140 \quad 09$ 9.03908690-05 7.1372081003 0.0

$7.42301650-02$ 2.33453720-05 $4.6690204 \mathrm{D}-09$ 2.3340445D-05 $2.33362470-05$ 4. $90164550-09$ 0.0 beta decaY DISIMIN

0.0

0.0

3. $5181318 D-09$

3.5227630D-09

0.0

0.0

4.0064654D-10

$6.04463350-10$ 2.03643790-10 0.0

7.9841200011

0.0

3.19800230 07 0.0

$3.2961342 D \quad 03$ 0.0

7.98848580-07 0.0

0.0

0.0

7.37974310-07 7.5234870D-07 1.50578700-08 0.0

0.0

0.0

0.0

0.0

8.65670340-05

$8.65672050-05$

0.0

0.0

0.0

0.0

4.66902260-09 0.0

2. $33362680-05$ 2. $33381580-05$ 
ISOGEN

\begin{tabular}{|c|c|c|c|}
\hline SIEP & DURA I IO & IN DF & Si \\
\hline 1 & $2.2500 E$ & 00 & \\
\hline 1 & $2.2500 E$ & 00 & \\
\hline 1 & $2.2500 \mathrm{E}$ & 00 & \\
\hline 1 & $2.2500 E$ & 00 & \\
\hline 1 & $2.2500 E$ & 00 & \\
\hline 1 & $2.2500 E$ & 00 & \\
\hline 1 & $2.2500 E$ & 00 & \\
\hline 1 & $2.2500 \mathrm{E}$ & 00 & \\
\hline 1 & $2.2500 E$ & 00. & \\
\hline 1 & $2.2500 E$ & 00 & \\
\hline 1 & $2.2500 E$ & 00 & \\
\hline i & $2.2500 E$ & 00 & \\
\hline 1. & $2.2500 \mathrm{E}$ & 00 & \\
\hline 1 & $2.2500 \mathrm{E}$ & 00 & \\
\hline 1 & $2.2500 \mathrm{E}$ & 00 & \\
\hline 1 & $2.2500 E$ & 00 & \\
\hline 1 & $-2.2500 \mathrm{E}$ & 00 & \\
\hline 1 & $2.2500 \mathrm{E}$ & 00 & \\
\hline 1 & $2.2500 \mathrm{E}$ & 00 & \\
\hline 1 & $2.2500 \mathrm{E}$ & 00 & \\
\hline 1 & $2.2500 E$ & 00. & \\
\hline 1 & $2.2500 \mathrm{E}$ & 00 & \\
\hline 1 & $2.2500 E$ & 00 & \\
\hline
\end{tabular}

*** RESULTS ***

SYMBOL

ATOMS

GRAMS

CUR IES

P02 10

$B 1210$

PB210

TL210

TL 206

TL206

PB206

U 235

PA231

TH231

TH227

AC227

RA223

RA223

FR223

RN219

AT219

P0215

BI215

PO211

B 1211

PB211

TL207

PB207
6. $0050202 \mathrm{D}-02$ 4.6109446D-03

6.7549358000

$9.33154160-09$

$3.4895872 \mathrm{D}-12$

4. 35135290-02

2.4443245021

1.5624004017

$1.702363 B D 08$

$6.38735370 \quad 05$

5.1656586000

$2.49326250 \quad 03$

3.04411830 00

5. 52997980-05

$1.23093190-05$

9.4799.309D-11

5. $746375 \mathrm{BD}-09$

$8.17356940-10$

$5.2242813 D-09$

$4.06898880-04$

$6.80057270-03$

. 97557240-04

3.68650580 .1
$2.0937313 \mathrm{D}-23$ $1.6076680 \mathrm{D}-2$ 2. $35519940-21$

3.2535678D-30

$1.19351650-33$

$1.48825960-23$

$9.69937900-01$

$6.09603380-05$

$6.5290731 \mathrm{D}-14$

$2.44974070-16$

$1.94687790-21$

$9.3968225 \mathrm{D}-1$

$1.1270771 \mathrm{D}-21$

2.04746070-26

$4.4757446 \mathrm{D}-27$

3.44696170-32

2.0512550D-30

$2.91767810-31$

$1.83019000-30$

$1.4254636 \mathrm{D}-25$

2.3824023D-24

$3.0847478 \mathrm{D}-2$

1.26698780-20
9. $40775820-20$ $1.99553820-19$ 2.06695920-19 $2.2072416 D-21$ $2.5941496 \mathrm{D}-25$ 0.0

5.94676910-02 $1.30081340-10$ $2.90392350-15$ $1.2983761 D-10$ $6.16423240-17$ $6.85214380-17$ $5.89269720-17$ B. $22194420-19$ $5.88260360-17$ $3.28876650-23$ $5.8825334 \mathrm{D}-17$ $3.19001150-23$ $1.88210870-10$ $5.88170230-17$ $5.88177870-17$ 5. $86279590-17$ 0.0
aLPHA DECAY DISIMIN

2.08917850-07 $5.76093200-13$ 0.0

0.0

0.0

1.3205910011

2.8886983002 $6.44870410-03$ 0.0

$1.36888920-04$

$1.82597640^{\circ}-06$

1.30636900-04

7. $30337860-11$

$1.30634810-04$

$7.08425230-11$

$1.3063328 \mathrm{D}-04$

0.0

4.17959410-07

1.30196880-04

0.0

0.0

0.0
BETA DECAY DISIMIN 0.0

4. $43148100-07$ 4. 5900663D-07 4.90161860-09 5. 76082090-13 0.0 0.0 0.0 $2.88329790 \quad 02$ 0.0

l. 50338750-04 0.0 1.825P717D-06 0.0 2.19100560-12 0.0

$7.08404570-11$ 0.0

4. $17967510-07$ 1. $30616490-04$ 1.30194900-04 0.0 
APPENDIX B. COMPUTER OPERATIONAL SEQUENCE 


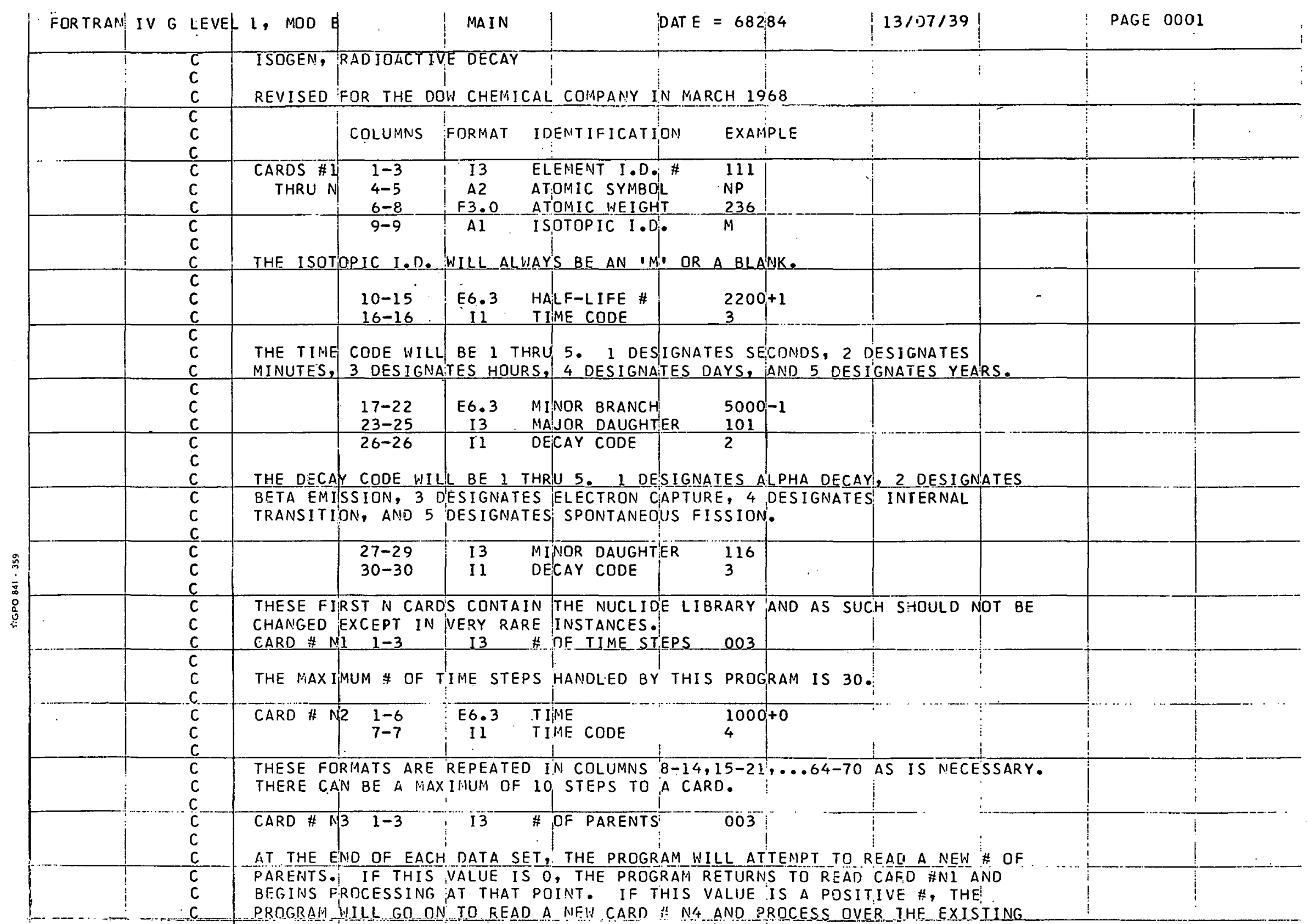




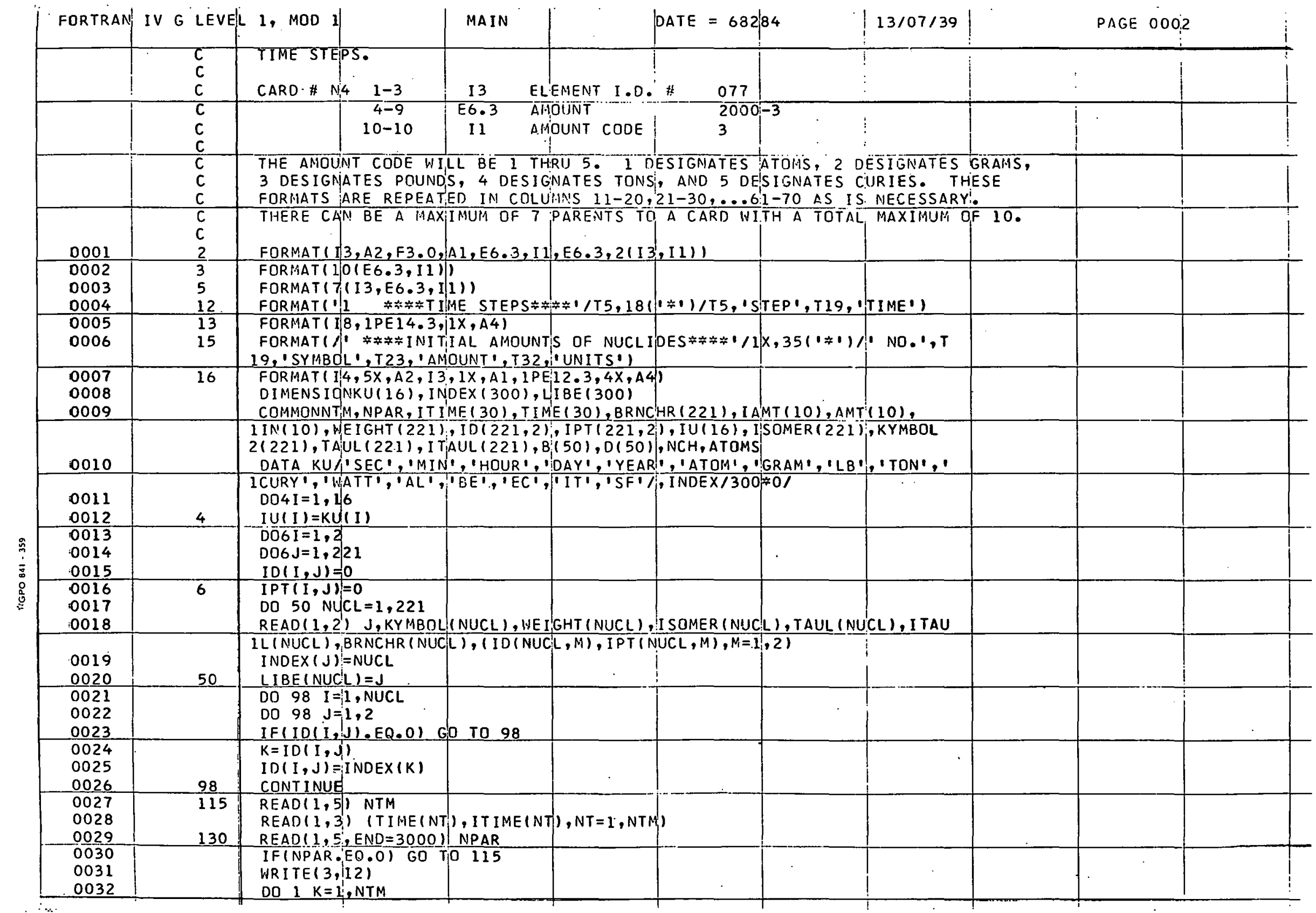




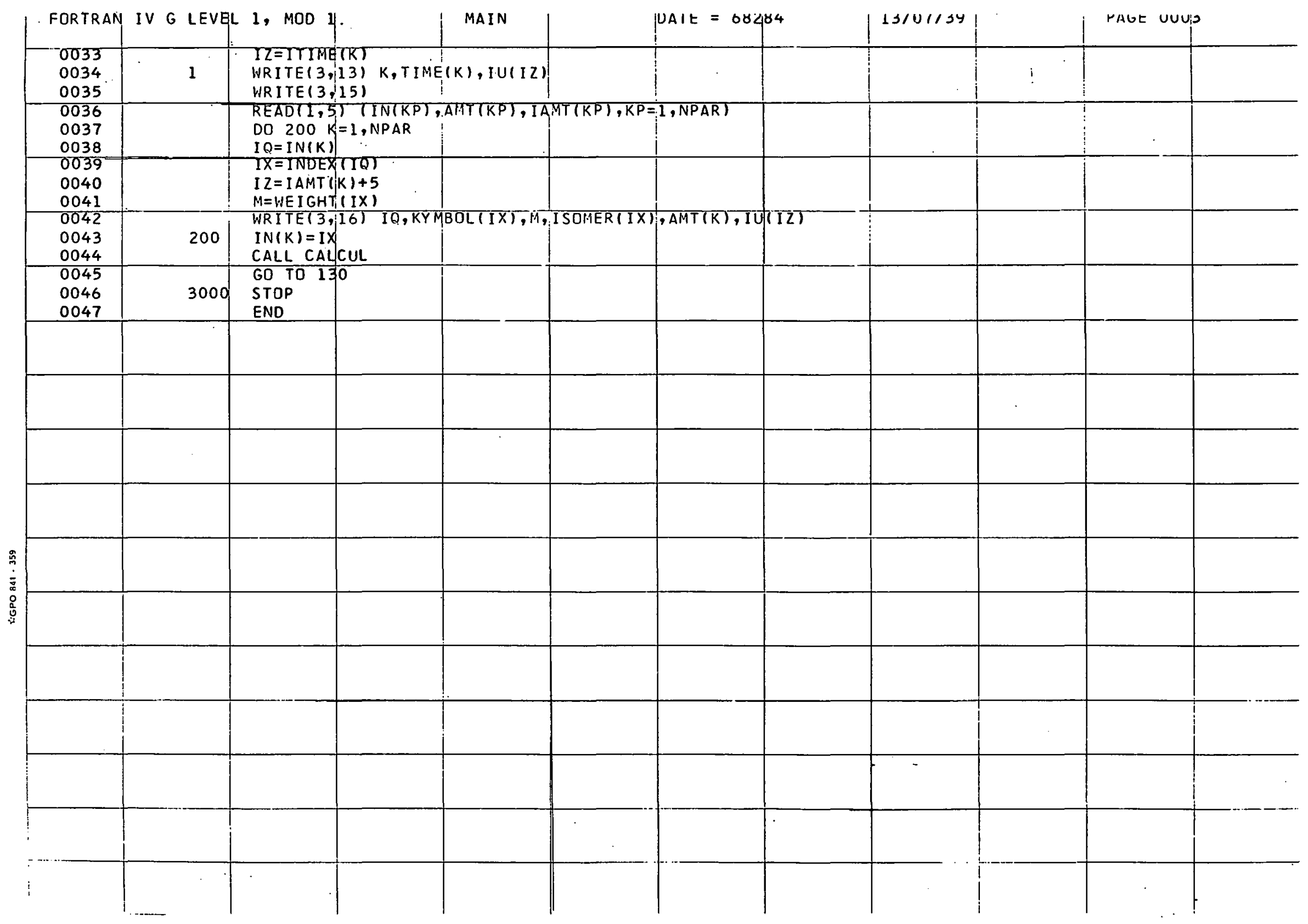




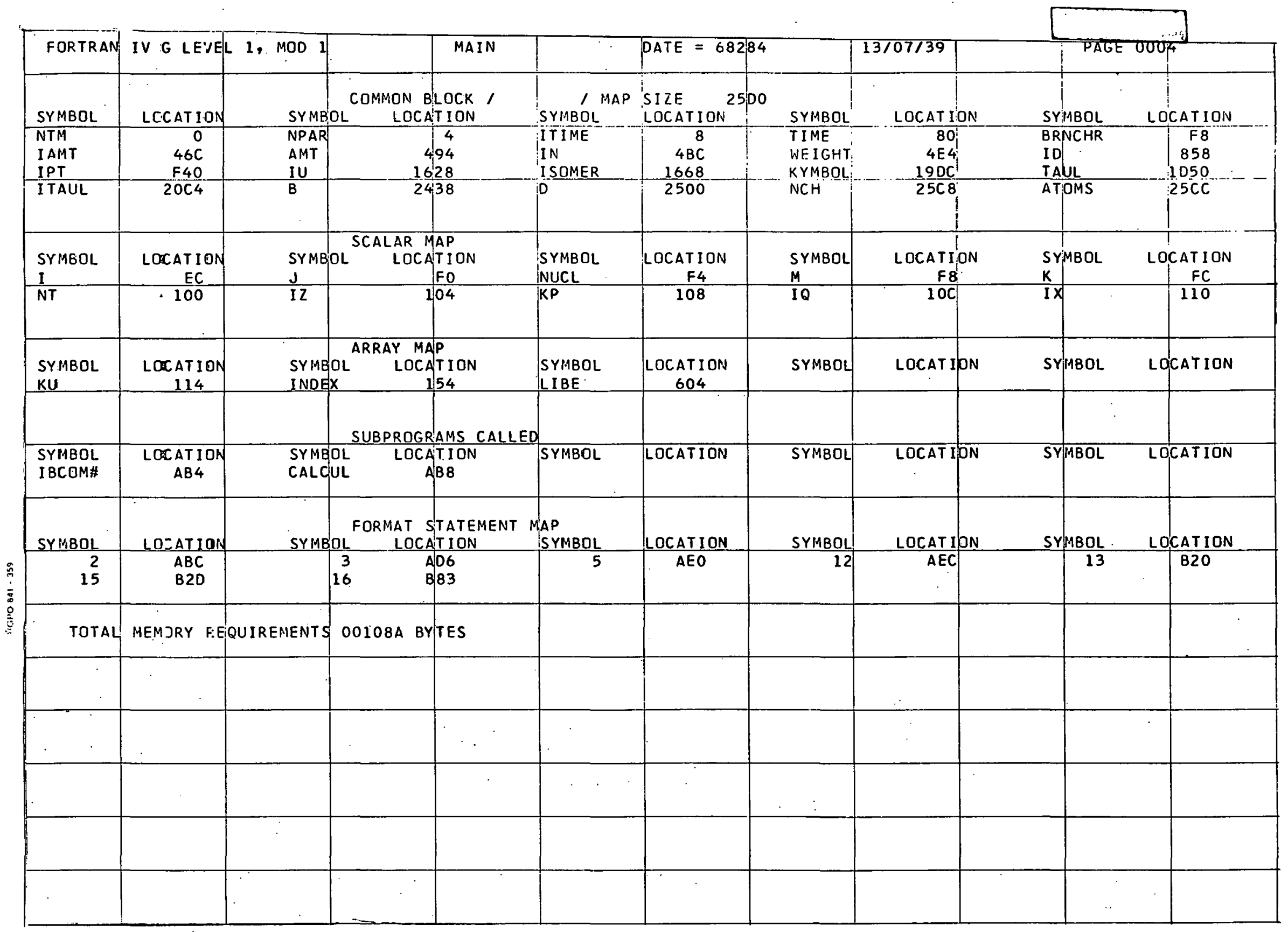




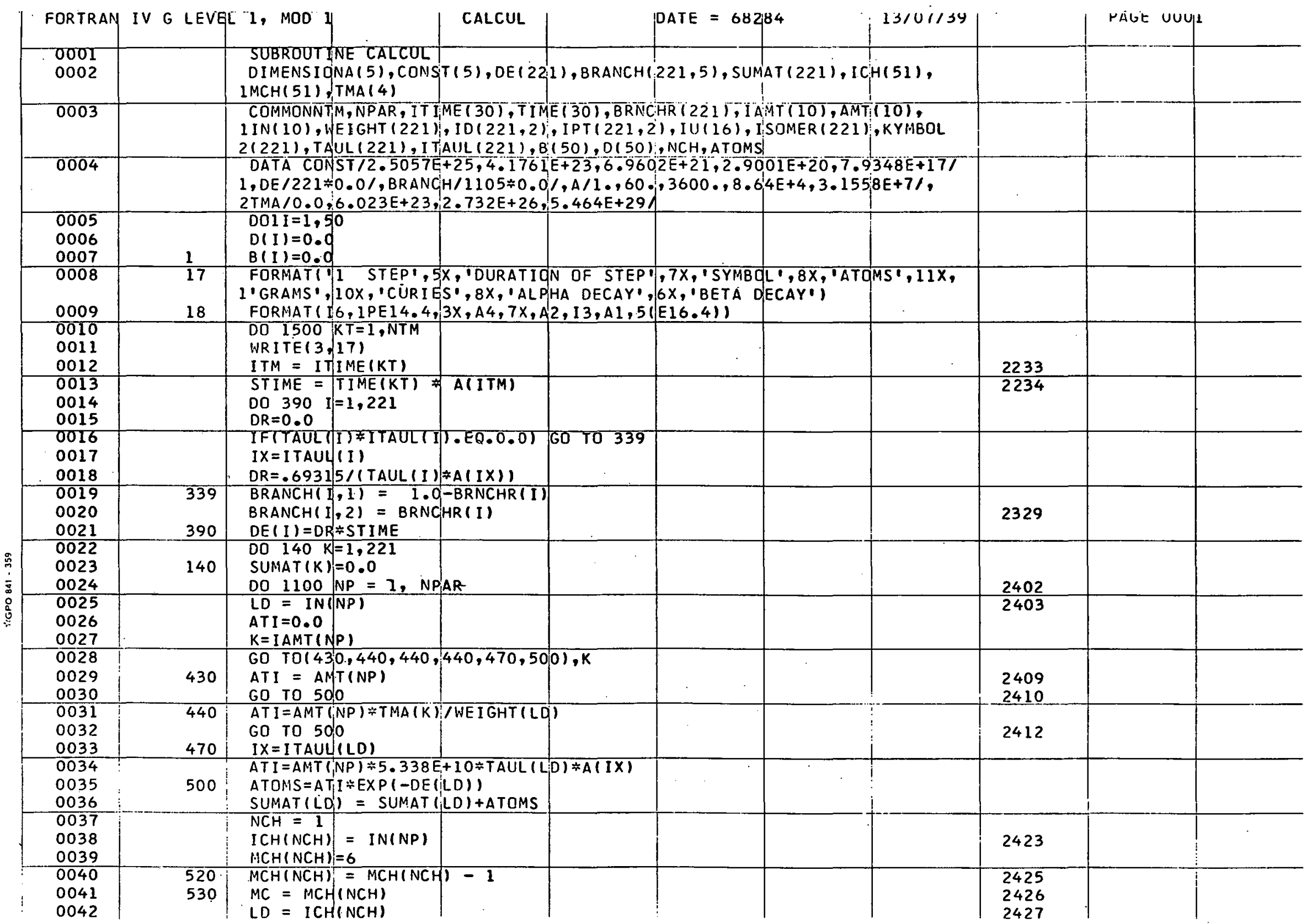




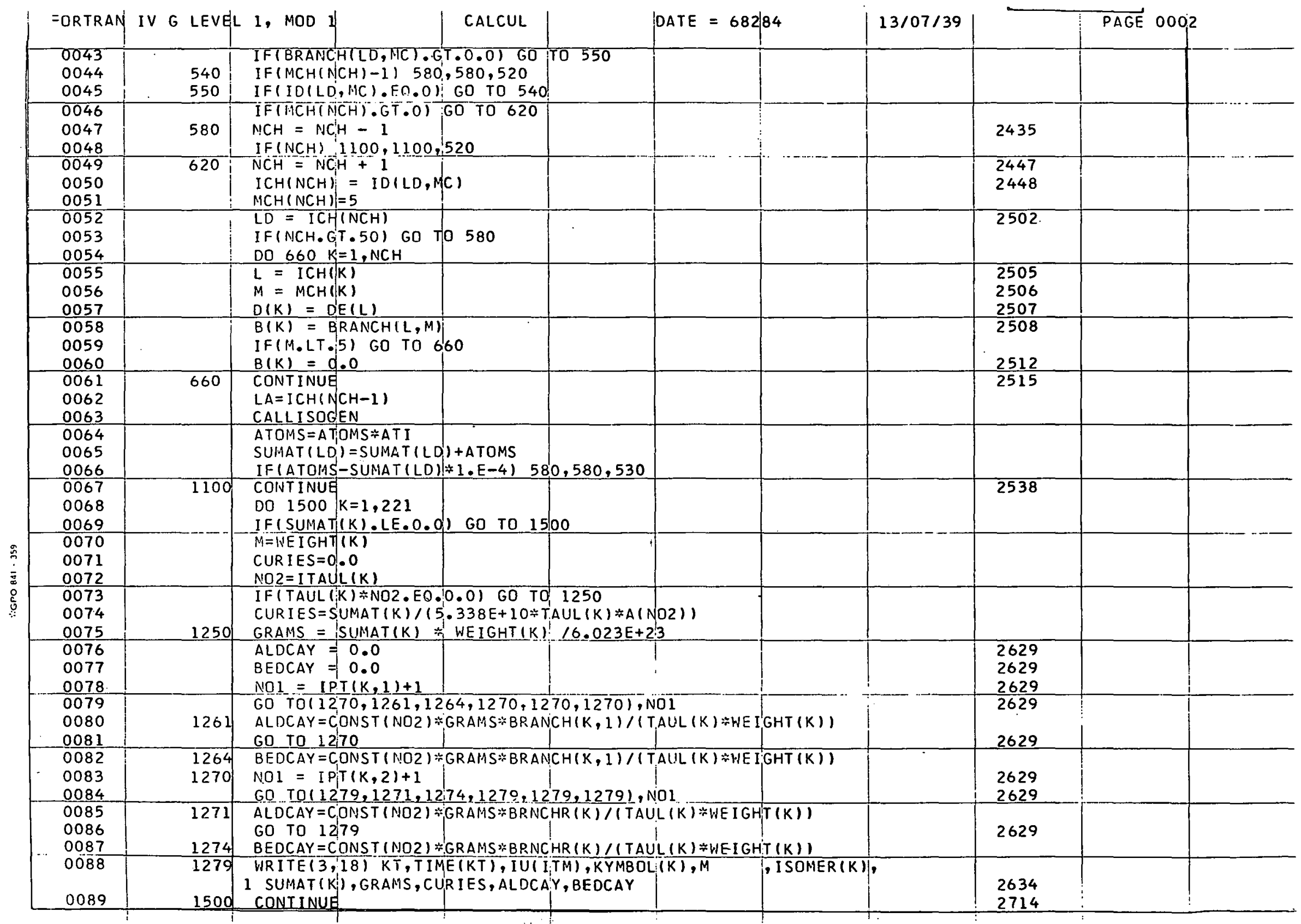




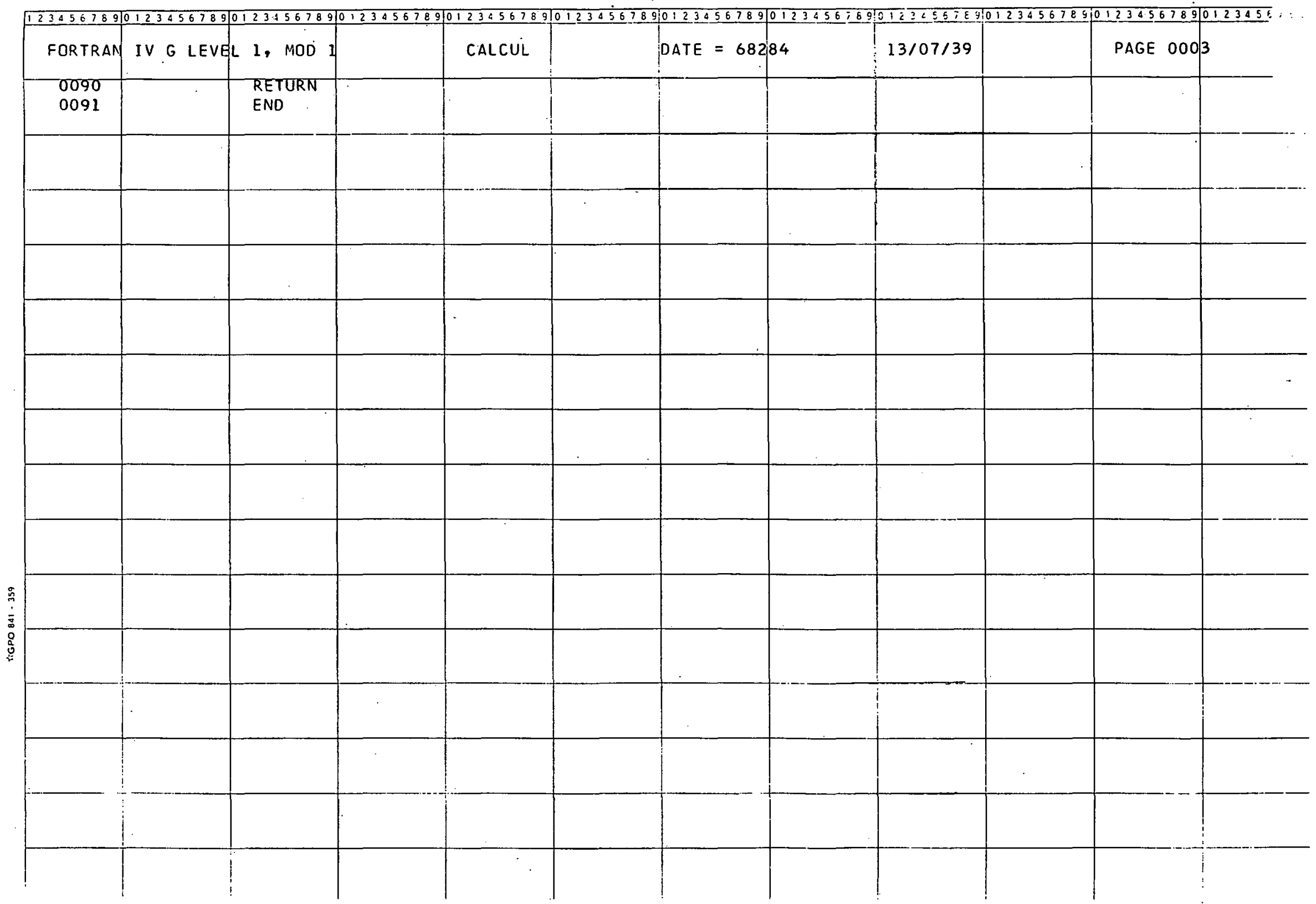




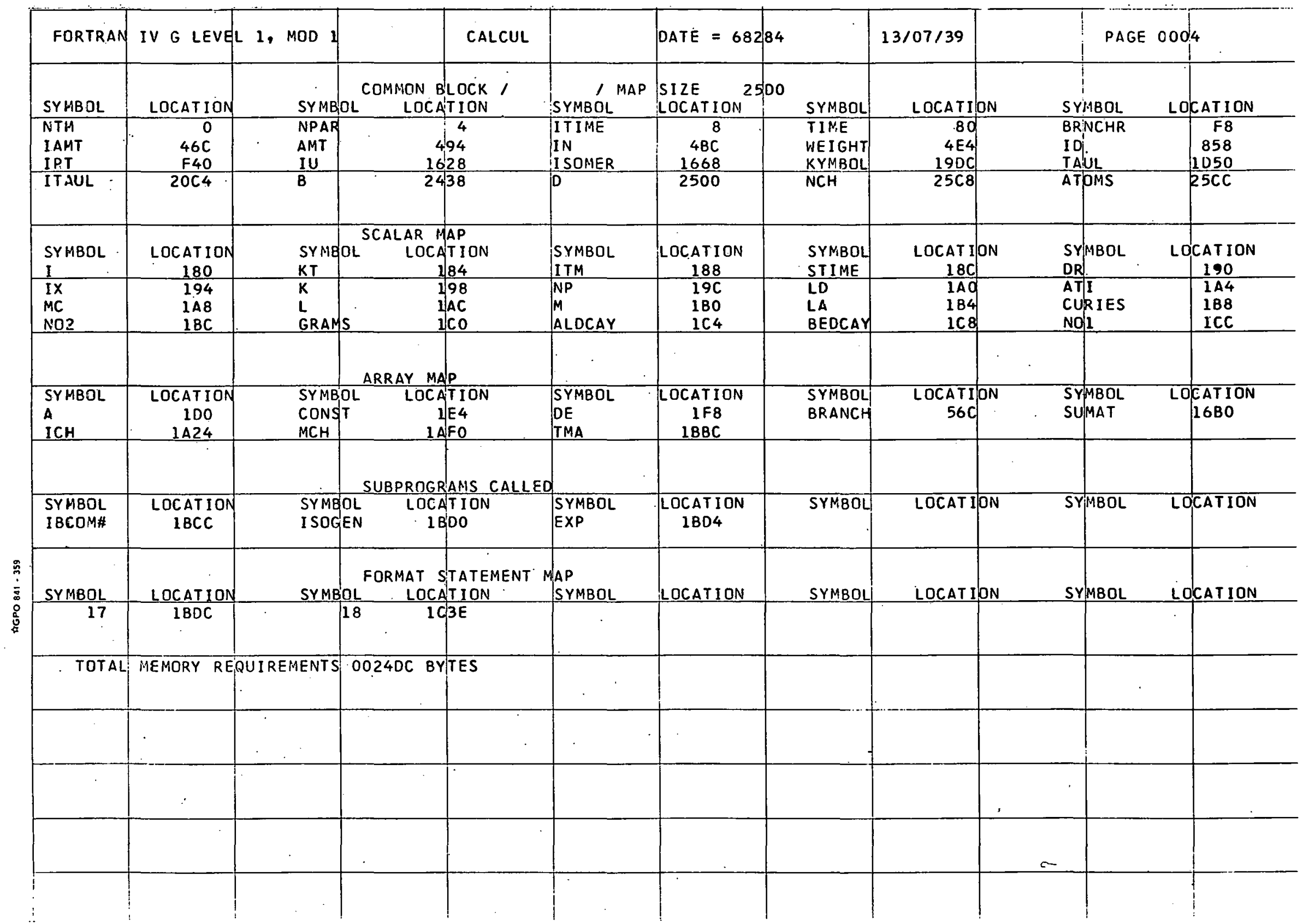














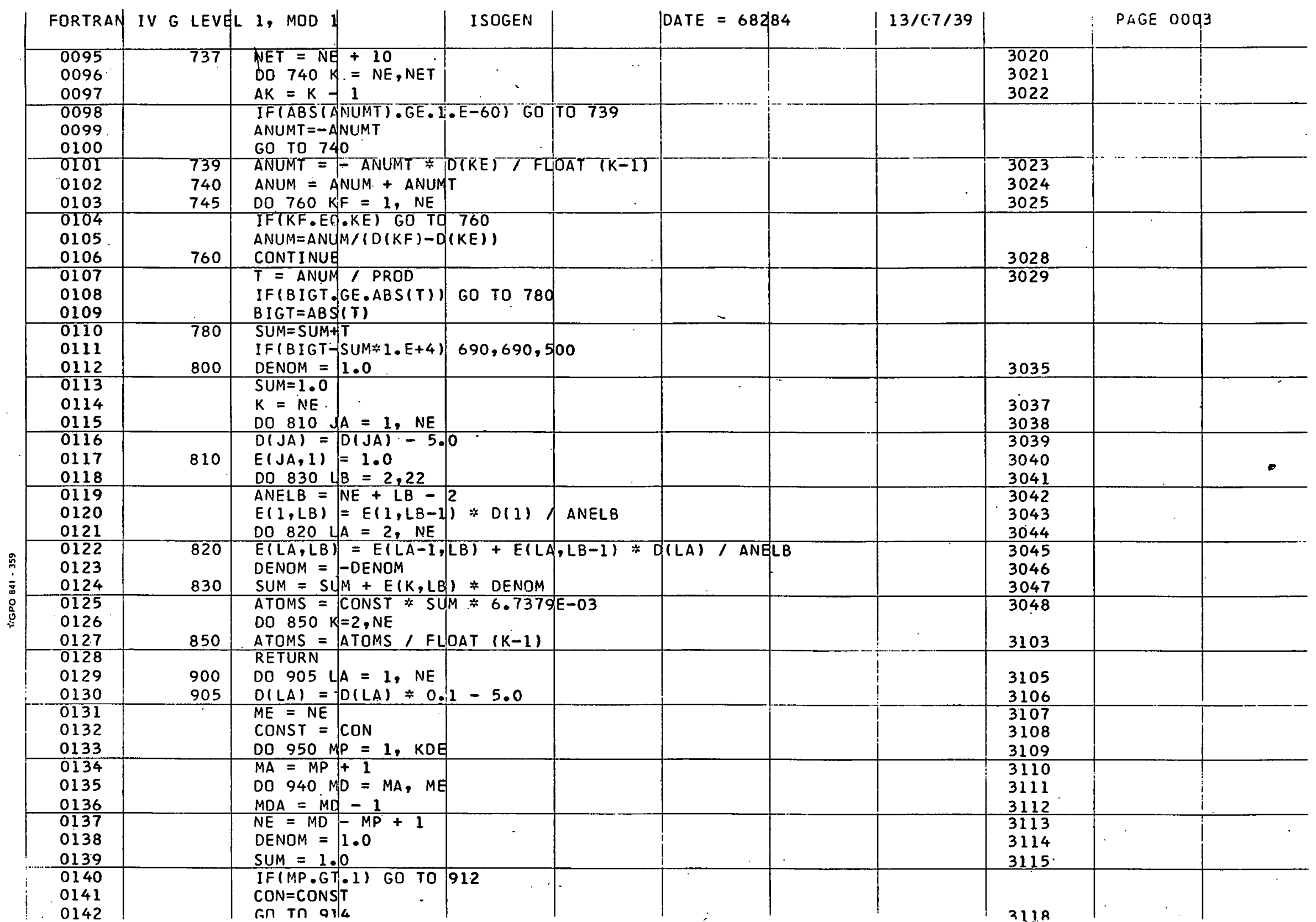




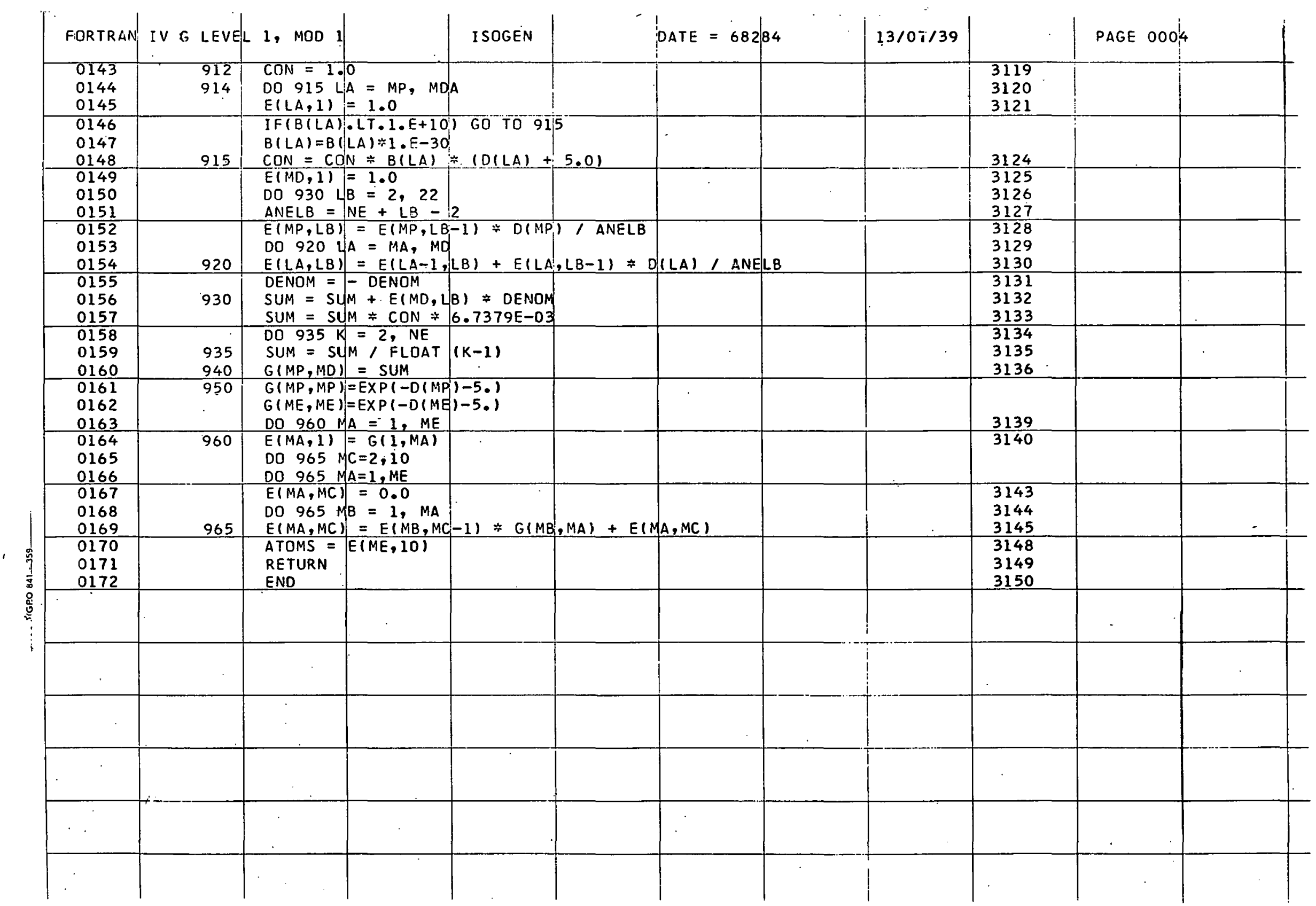




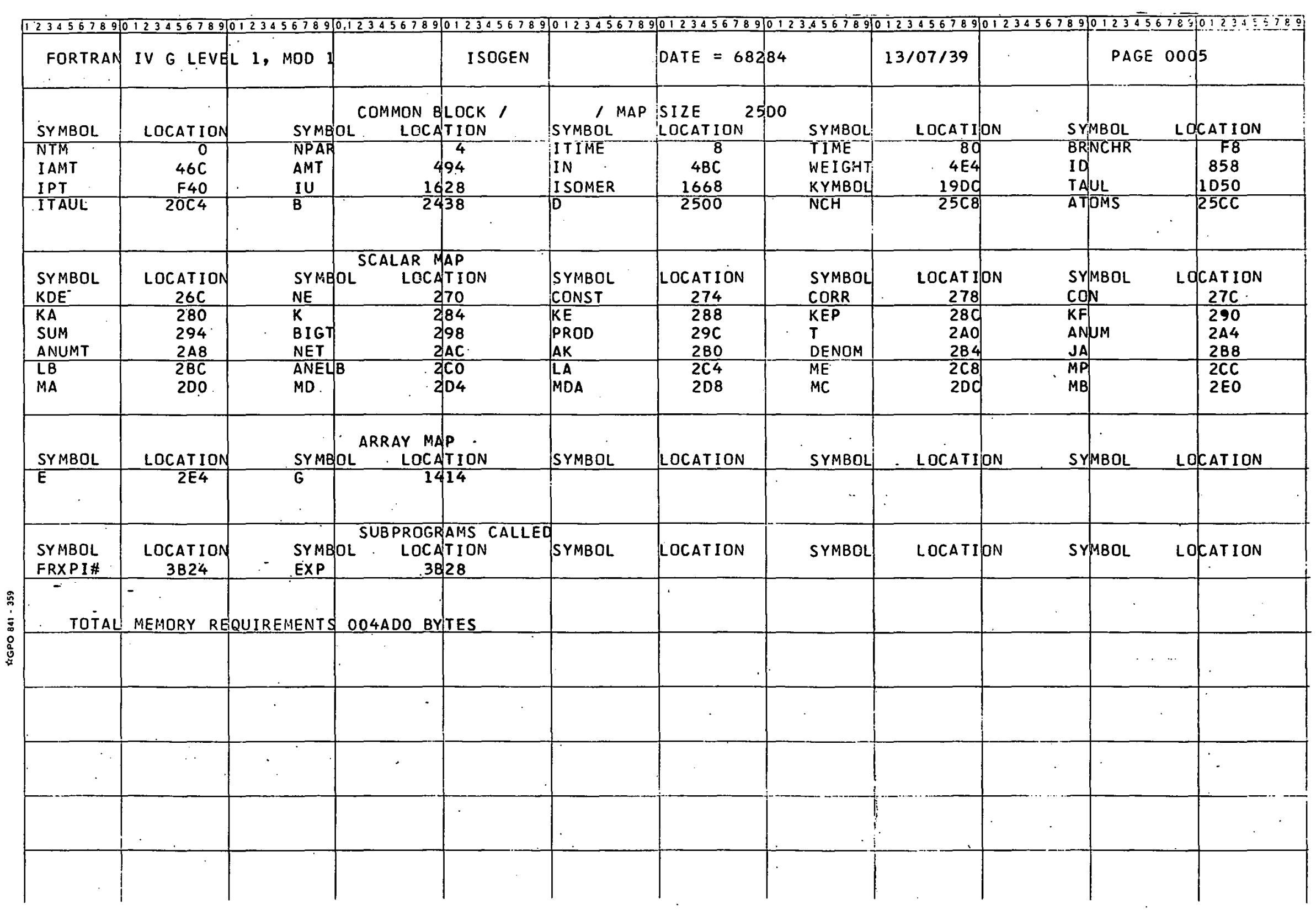


APPENDIX C. MONIFIED ISOGEN PROGRAM FLOW CHART 
MAIN PROGRAM

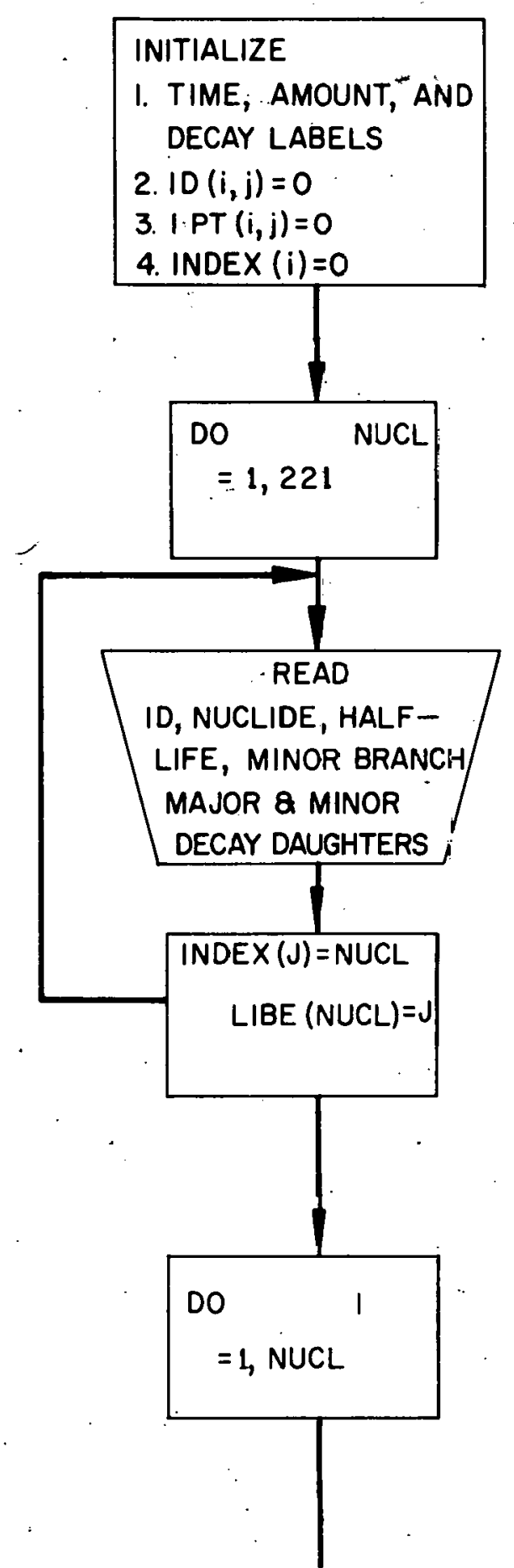









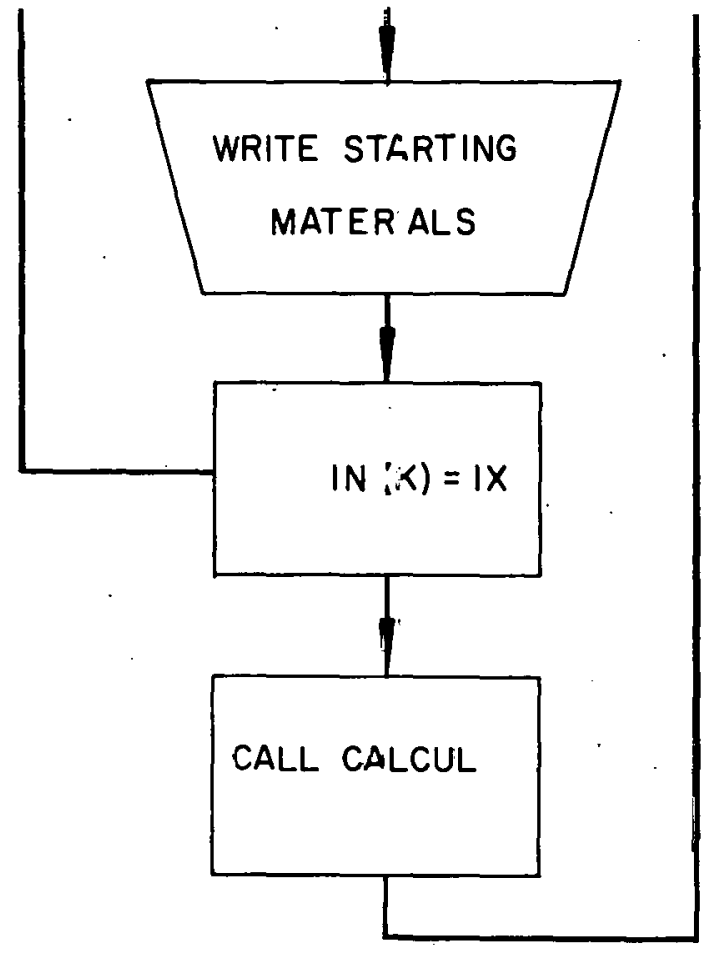




\section{SUBROUTINE CALCULATIONS}






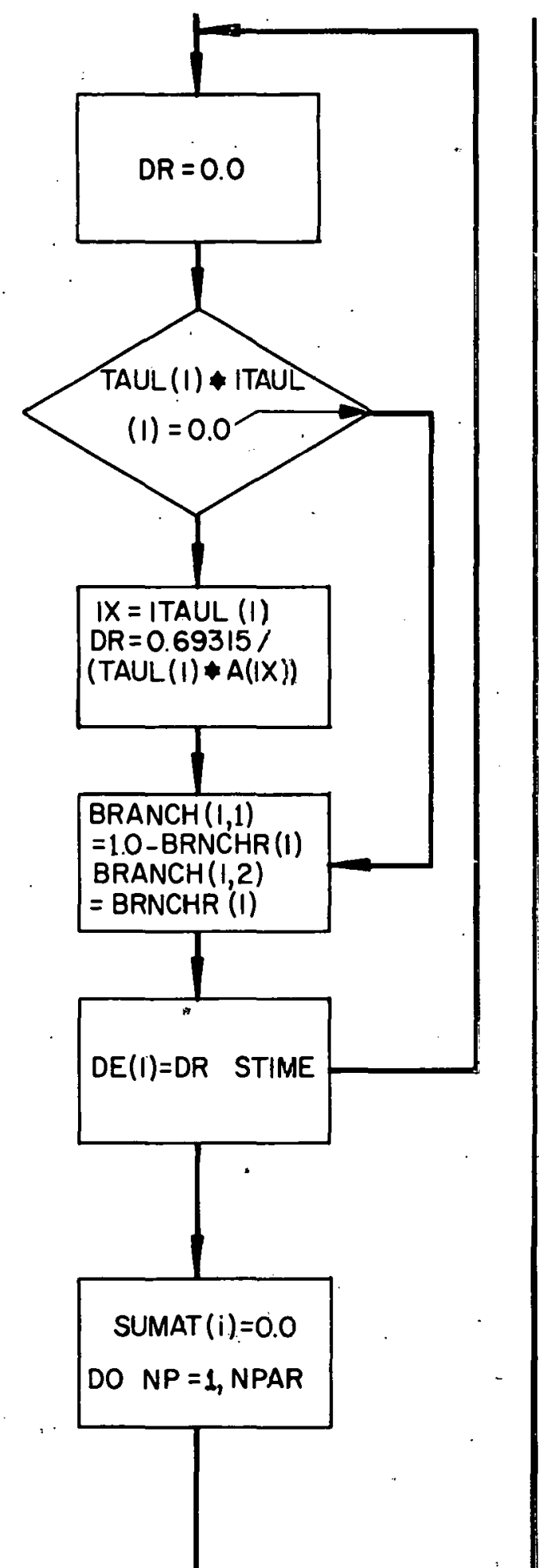




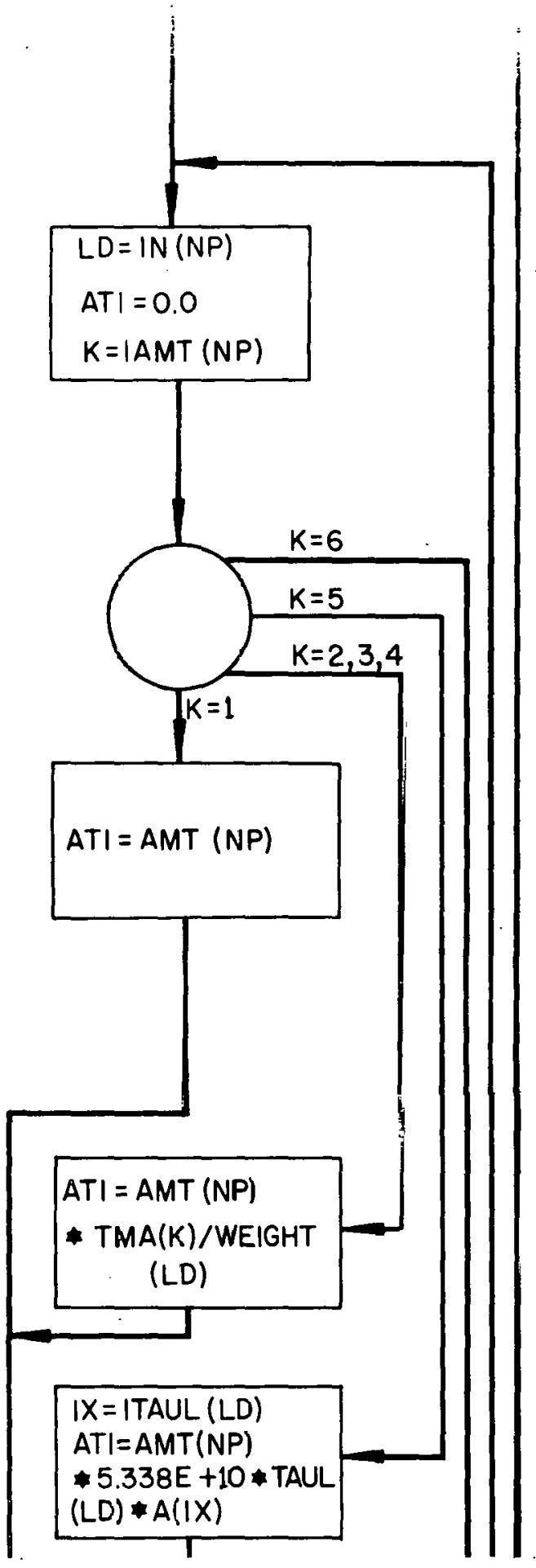




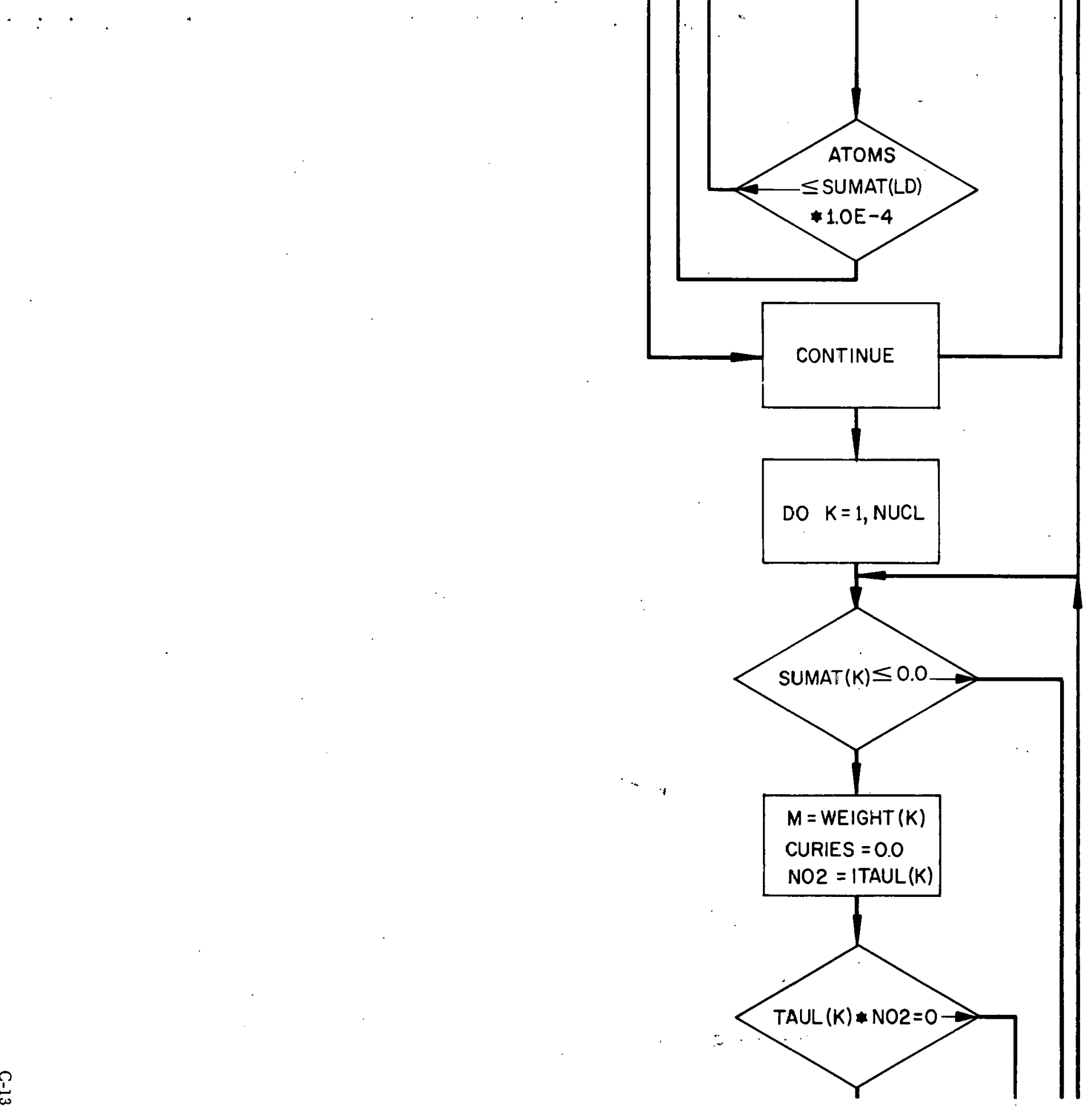




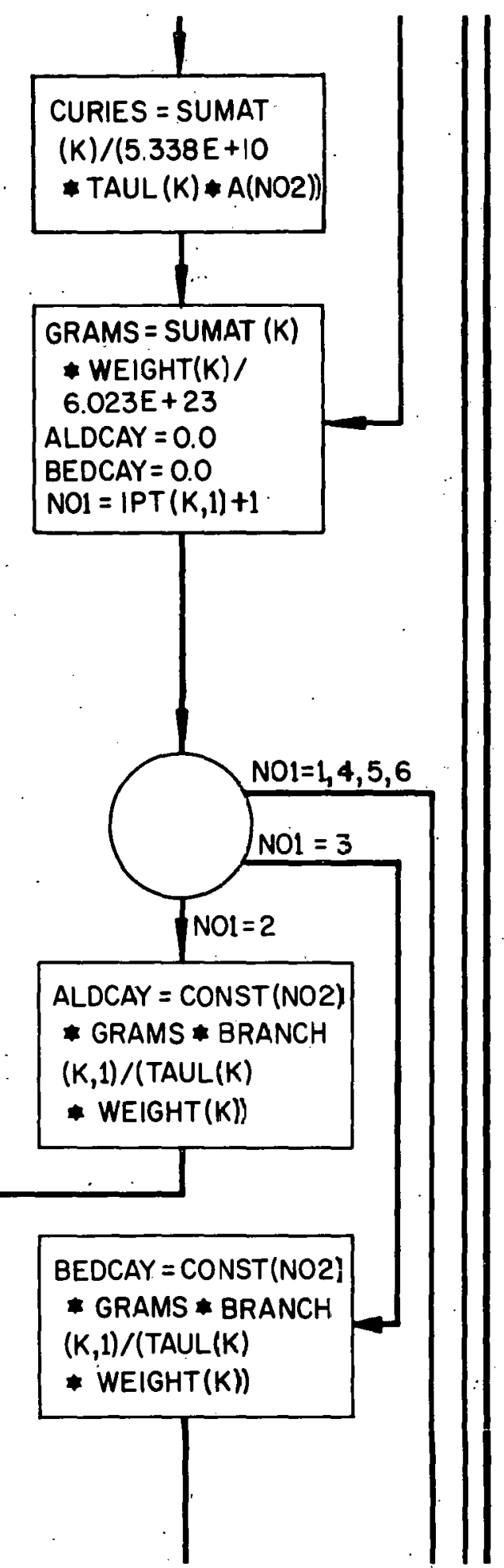




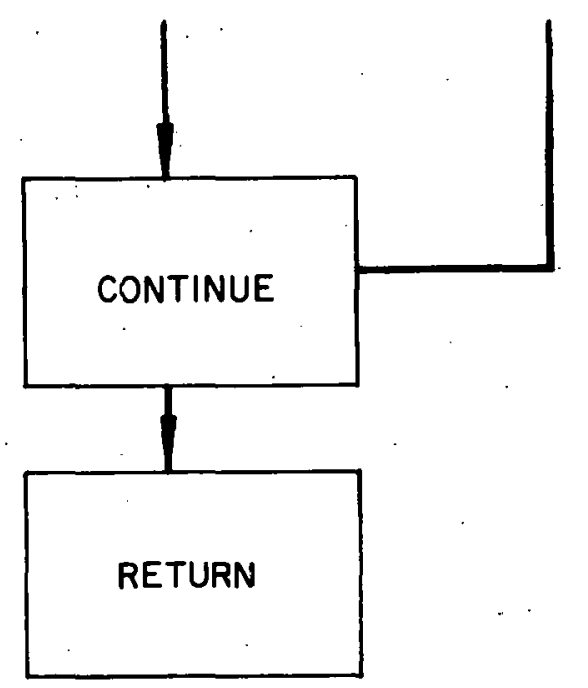


SUBROUTINE ISOGEN











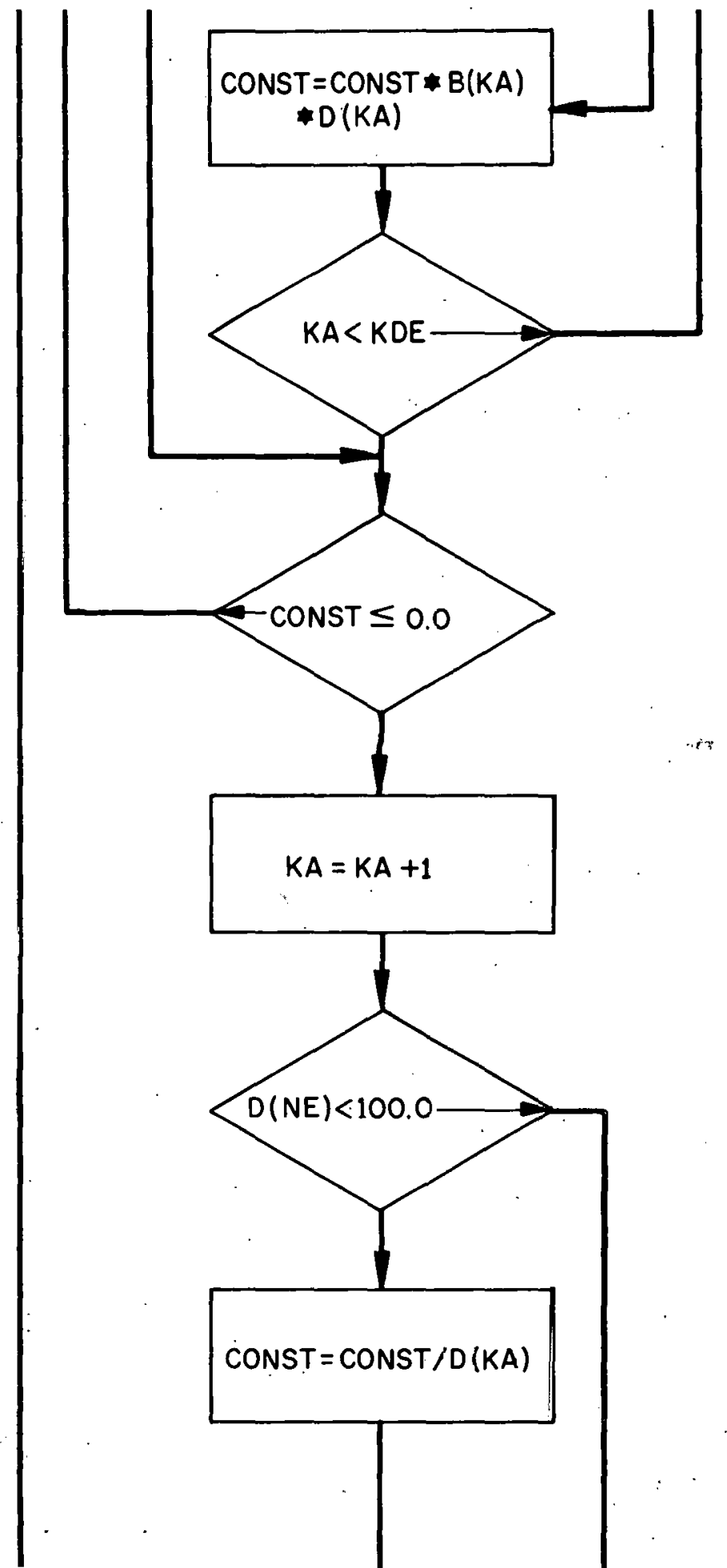




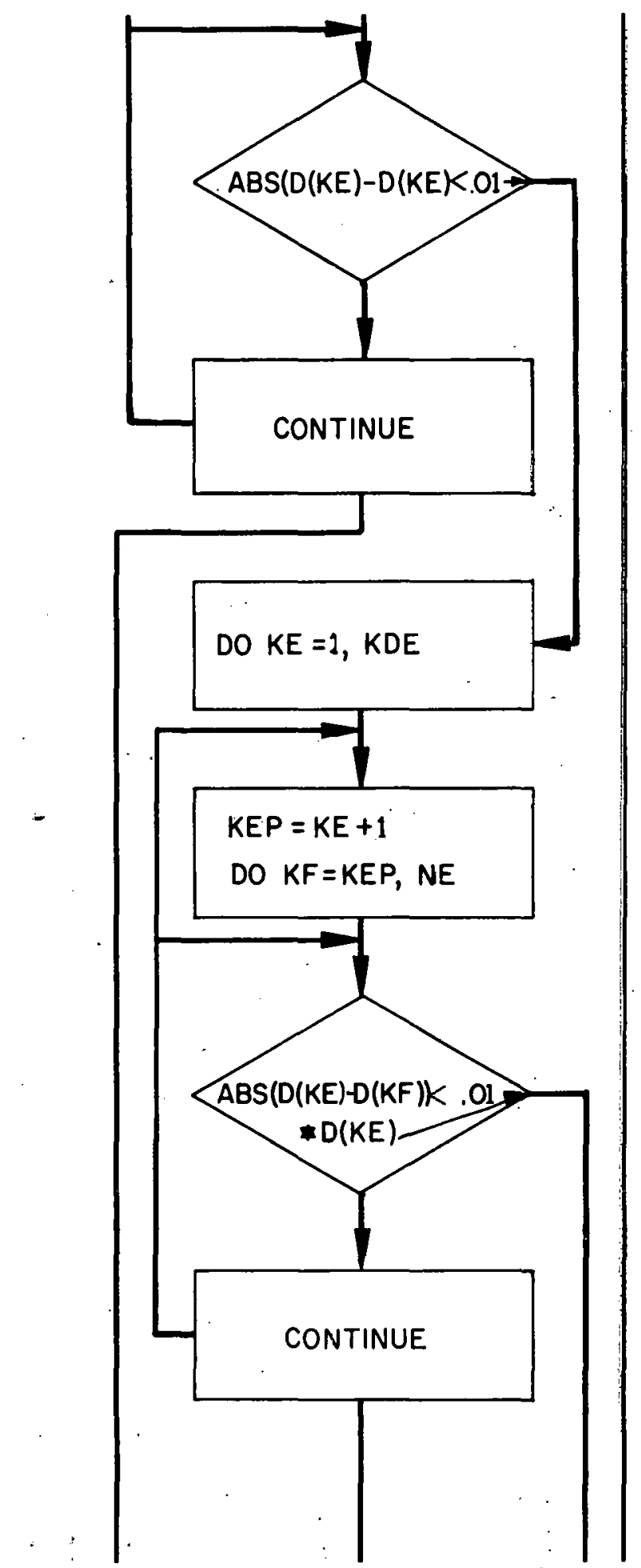




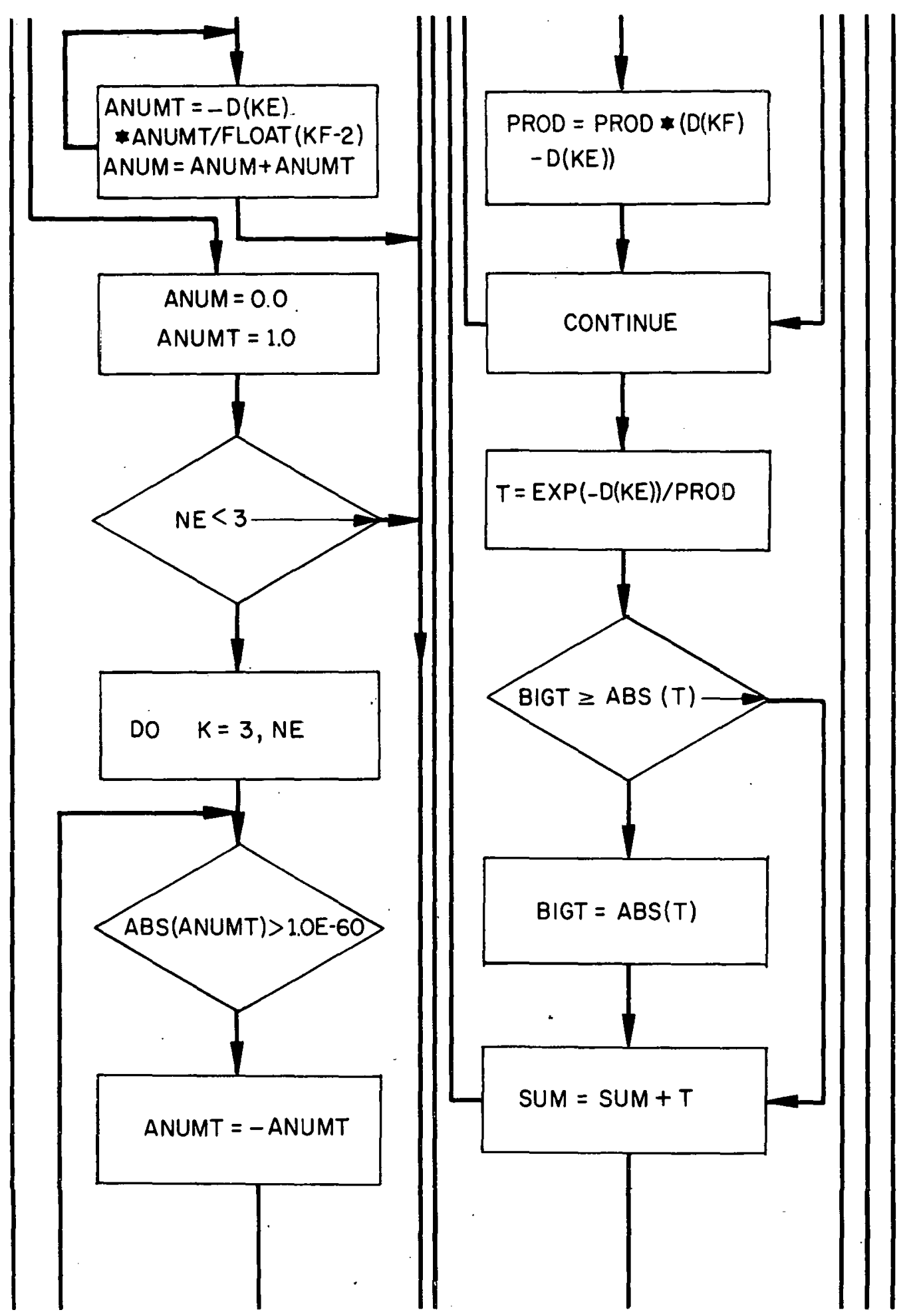




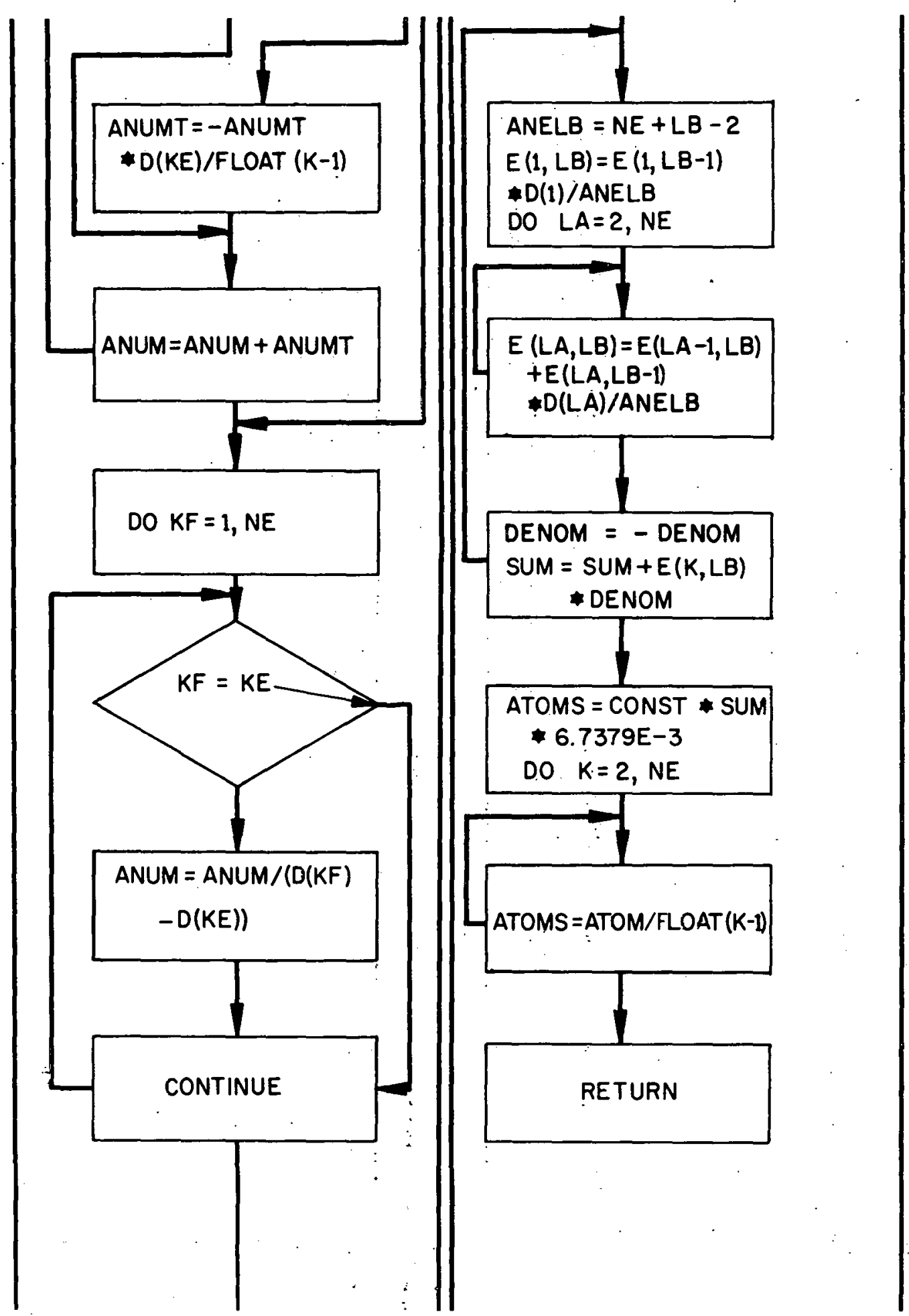




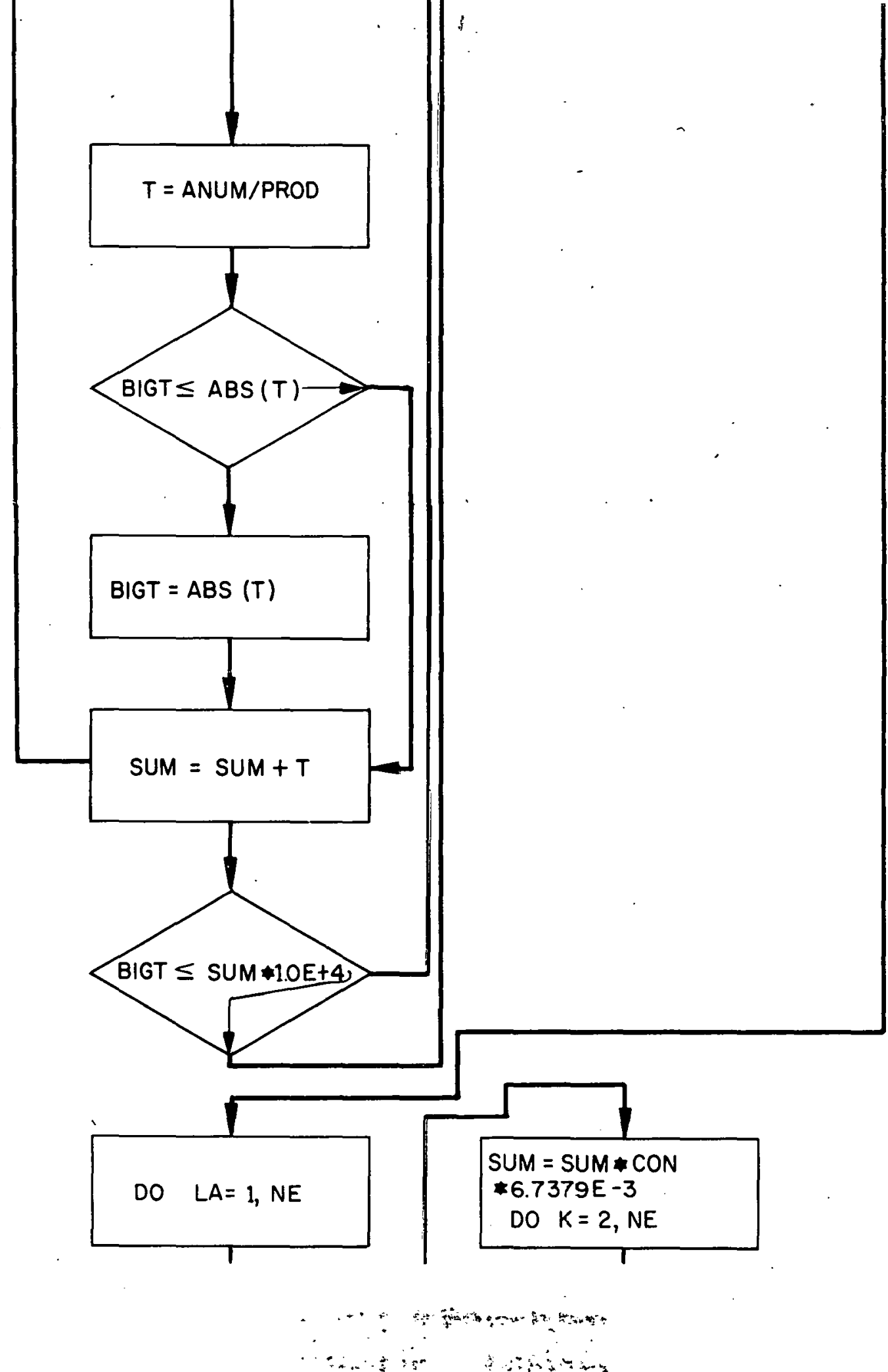




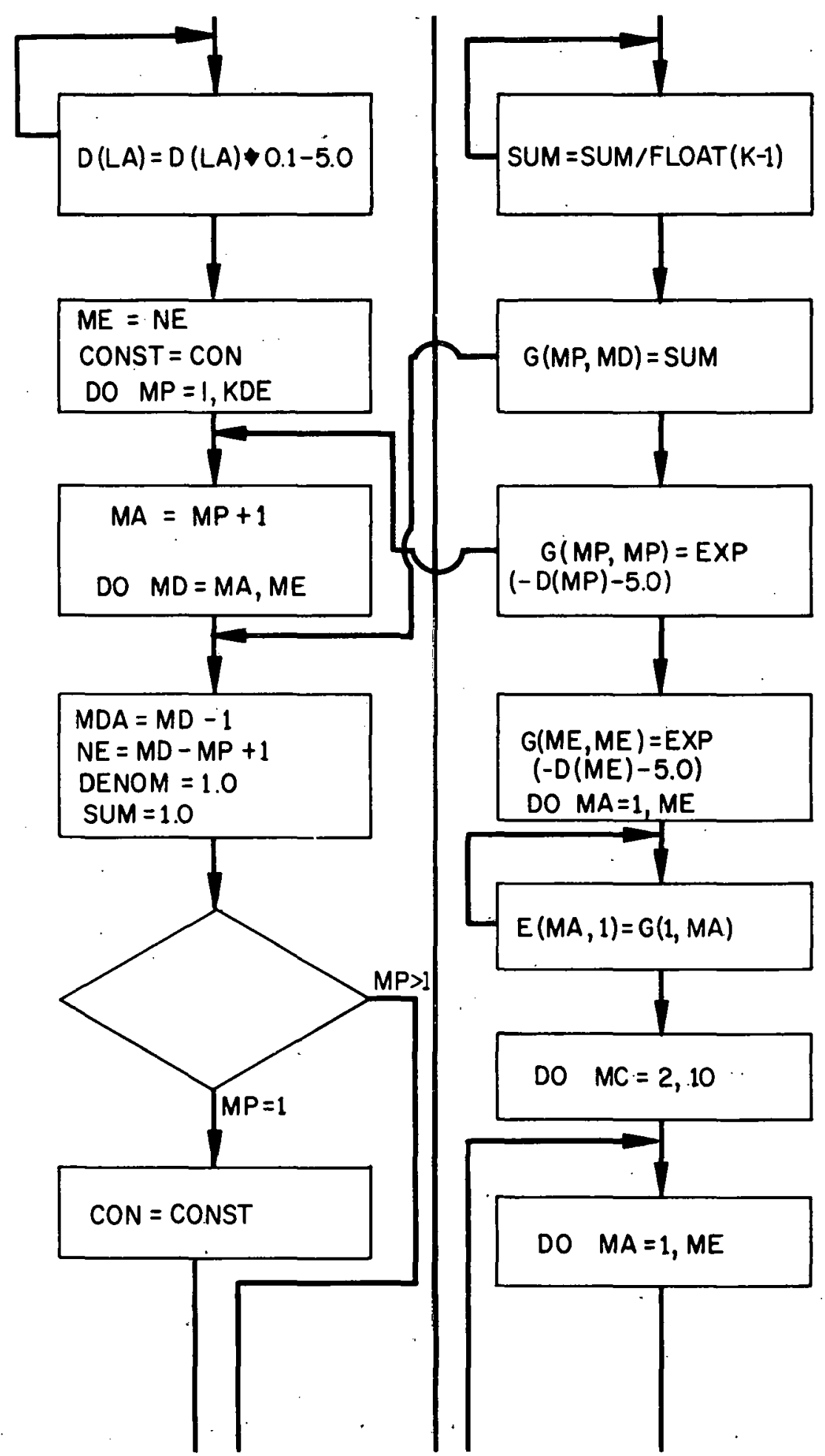




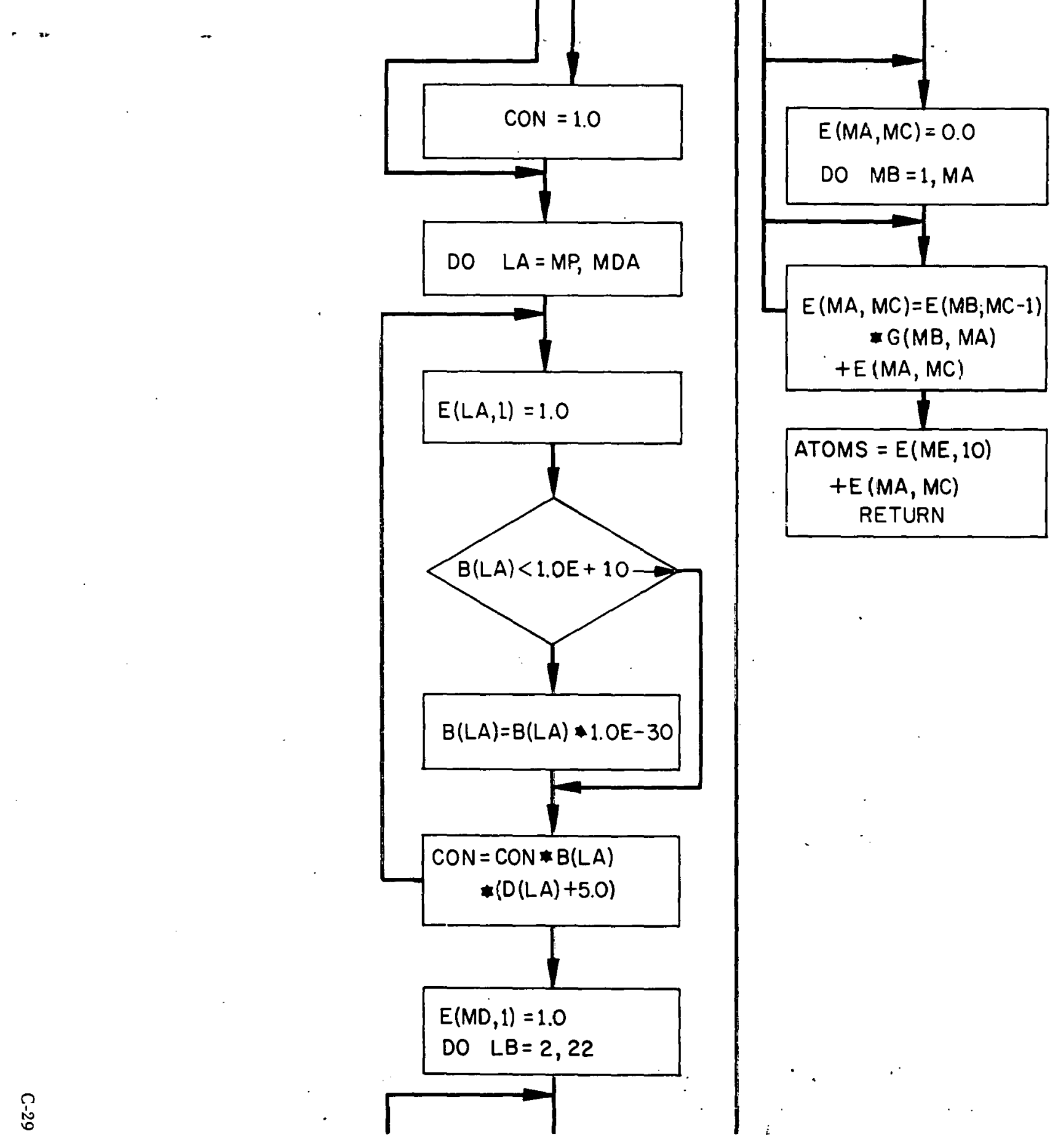






